\title{
ARTICLES
}

\section{Law as "The Common Thoughts of Men": The Law-Teaching and Judging of Thomas McIntyre Cooley}

\author{
Paul D. Carrington*
}

In this article, Professor Carrington offers an intellectual history of Thomas McIntyre Cooley. Cooley, a close contemporary of Dean Langdell, was in his time the premier judge, law teacher, and legal scholar in America, overshadowing not only Langdell, but his somewhat younger associate, Oliver Wendell Holmes. The twentieth century has neglected, even scorned, Cooley, while elevating Langdell and Holmes: Langdell as the patron of a technocratic profession trained by Hessians, and Holmes as the patron of a disengaged academic subprofession. In the Jacksonian universe producing Cooley, there was little appreciation of the likes of either Langdell and his successors, or Holmes and his. This article compares the law teaching of Cooley to that of Langdell, and his judging to that of Holmes, and imagines that Cooley might in the twenty-first century regain some of the respect he lost in the twentieth.

Harvard celebrated its 250 th anniversary in November 1886 . It was a time for self-praise in Cambridge. ${ }^{1}$ Among the events marking the occasion was the award of an honorary doctorate to Thomas McIntyre Cooley of Ann Arbor, Michigan. At this time, Cooley was the most respected lawyer in America and among the most widely respected persons in American public life. ${ }^{2}$ Nothing could have been more appropriate than that he be invited to honor Harvard with a ceremonial utterance.

* Chadwick Professor of Law, Duke University. The author is grateful to George Christie, Anthony D'Amato, Martin Golding, Stanley Hauerwas, Jefferson Powell, and Terrance Sandalow for useful comments on earlier drafts. Claire Fried Drake, Erika King, and David Shapiro helped with the documentation.

1. See Harvard Univ., A Record of the Commemoration, November Fifth to Erghth, 1886, On the Two Hundred And Fifiteth AnNiversary of the Founding of Harvard Coliege (Cambridge, John Wilson \& Son, Univ. Press 1887) [hereinafter HARvard, A ReCord OF COMMEMORATION].

2. See aran R. Jones, The Constitutional Conservatism of Thomas Mcintyre Cooley (Harold Hyman \& Stuart Bruchey eds., 1987); Harry Bums Hutchins, Thomas McIntyre Cooley, in 7 GREAT AMERICAN LAWYERS 445 (William D. Lewis ed., 1909); Henry Wade Rogers, Thomas McIntyre Cooley, in Distinguished American Lawyers 205 (Henry W. Scott ed., New York, Charles L. Webster \& Co. 1891). 
In 1884 , Cooley had retired from a quarter century of service as the founding dean, esteemed teacher, and intellectual leader of the University of Michigan Law School, a school which had for a time surpassed Harvard's in its ability to attract students. ${ }^{3}$ His former students, among them, future Justices Day and Sutherland and Clarence Darrow, were so active in public life that they might also have surpassed Harvard's alumni in service to the republic.

In addition to educating law students, Cooley was elected in 1865 to the Supreme Court of Michigan and served that court for twenty years, many of them as Chief Justice, often as its intellectual leader. ${ }^{4}$ His court was regarded in the 1870s as possibly the ablest appellate court in America..$^{5}$ Many lawyers had favored and some had sought his appointment to the Supreme Court of the United States. Indeed, a leading legal publication, the Central Law Journal of St. Louis, spoke of his qualifications as "transcendent."6 However, Cooley's appointment was withheld, apparently because he was viewed by the barons of his Republican party as too independent. ${ }^{7}$ His judicial career ultimately came to an end in 1885 when he was defeated for reelection in a tide of Democratic votes. ${ }^{8}$

Although Cooley's teaching and judicial careers garnered distinction, his professional legal writing won him the greatest fame. In 1868, he published his Constitutional Limitations, ${ }^{9}$ a work recounting and comparing the interpretations of the constitutions of the states and those few provisions of the antebellum federal Constitution applicable to state governments. In 1886, that work was still the most scholarly and certainly the most admired American law

3. From 1869-70, Michigan had 308 law students, and Harvard had 120. See ALfred ZantZINger Reed, Training for the Public Profession of the Law: Hrstorical Development and Principal Contemporary Problems of Legal Education in the Untted States with Some Account of CONDITIONS IN ENGLAND AND CANADA 423 app. at 452 (1921). For a general history of the University of Michigan Law School, see Elizabetr Gaspar Brown, Legal Education at Michigan, 1859-1959 (1959).

4. See JONES, supra note 2, at 168 (noting that "[w]ithin a few years after 1865 Cooley was respected as a natural leader of the court"); $c f$. Book Note, 4 S.L. Rev. 883 (1879) (reviewing cases decided in the Supreme Court of Michigan from June 12, 1877 to November 1, 1877).

5. See generally Edward M. Wise, "The Ablest State Court": The Michigan Supreme Court Before 1885, 33 WAYNE L. REv. 1509 (1987) (describing the noteworthy characteristics of the Cooley court). See also Note, Mr. Justice Cooley, 32 Am. L. REv. 916, 918-19 (1898) (stating upon Cooley's death that the talent of its members placed the Supreme Court of Michigan "in the very first rank of American State courts"). The American Law Review, edited in Boston by John Chipman Gray, and then by Oliver Wendell Holmes, gave much attention to the decisions of the Supreme Court of Michigan. See, e.g., Book Notice, Michigan Reports, 6 AM. L. REv. 558 (1872) (reviewing Michigan Supreme Court cases decided between Jan. 5, 1870 and Oct. 21, 1870); Book Notice, Michigan Reports, 3 AM. L. Rev. 757 (1869) (reviewing Michigan Supreme Court cases decided between April 28, 1868 and January 11, 1869); Book Notice, Report of Cases Heard and Decided in the Supreme Court of Michigan, from July 11, 1867, to April 28, 1868, 3 AM. L. Rev. 141 (1868).

6. See Rogers, supra note 2, at 205, 218 (declaring Cooley "eminently fit" for a Supreme Court appointment); see also Note, Mr. Chief Justice Fuller, 22 AM. L. Rev. 475, 477 (1888) (lamenting that, despite his outstanding qualifications, Cooley was overlooked in nominations to the Supreme Court).

7. See Jones, supra note 2, at 212,216 (discussing Cooley's outspoken criticism of Republican policies).

8. For discussion of the election, see text accompanying notes 338-345.

9. Thomas M. Cooley, a Treatise on the Constitutional limitations which Rest Upon the Legislative Power of the States of the American Unon (Boston, Little, Brown \& Co. 1868). 
book. ${ }^{10}$ It was then in its fifth edition, and a reviewer of that edition expressed the prevailing opinion when he said that

[i]t is impossible to exaggerate its merits. It is an ideal treatise, and not only a standard authority, but almost exclusively sovereign in its sphere. It is cited in every argument and opinion on the subjects of which it treats, and not only is the book authoritative as a digest of the law, but its author's opinions are regarded as almost conclusive. ${ }^{11}$

In 1873, Cooley also published a new edition of Joseph Story's Commentaries on the Constitution of the United States, 12 adding to that dated but popular work an account of the recent post-Civil War amendments that imposed new restraints on the powers of state governments. ${ }^{13}$ In 1876 , he published a useful treatise on taxation, ${ }^{14}$ a work that, like its predecessors, analyzed judicial interpretations of constitutional provisions. Three years later, he published yet another treatise, this one on torts, then a newly emerging field of private law-a work in which he lucidly described the role of an American common law court. ${ }^{15}$ In 1880, he published a short text, The General Principles of Constitutional Law, ${ }^{16}$ that was required reading at the Harvard Law School for students enrolled in James Bradley Thayer's course in Constitutional Law. ${ }^{17}$ While several of these works would be the objects of later editions prepared by other hands, Cooley had by 1886 ceased his endeavors as a legal writer. ${ }^{18}$

Although by 1886 Cooley would not again judge, teach, or (with one exception $)^{19}$ write law, his career as a lawyer was not yet at an end. He remained in demand both as a speaker and as an author of articles in popular periodicals, discussing public issues of the day with legal dimensions. ${ }^{20} \mathrm{He}$ also served on an advisory commission in the resolution of several disputes involving the railroad industry, 21 then America's largest and most complex. When the Interstate Commerce Act was approved in 1887, its passage spawned great concern over

10. In 1901, the publisher boasted that the work had the widest circulation of any legal treatise published after 1850, and that no other work had "been cited more freely or with a greater measure of commendation." JoNes, supra note 2, at 122 n.l (quoting a letter from F.N. Lincoln to Henry W. Rogers, July 1, 1901).

11. Book Note, 27 ALB. L.J. 300 (1883) (reviewing Cooley's treatise).

12. Joserh Story, Commentaries on the Constitumion of the United States (Boston, Little, Brown, 4th ed. 1873) (1833) (notes and additions by Cooley).

13. See id.

14. See Thomas M. Cooley, The Law of Taxation (4th ed. 1924) (1876). For contemporary comment on the taxation treatise, see Morton J. Horwtrz, THE Transformation of AMERICAN LAw, 1870-1960: THE CRISIS OF LEGAL ORTHODOXY 20-22 (1992) (recognizing Cooley's important contributions to constitutionalizing the law of taxation).

15. See Thomas M. Cooley, a Treatise on the LaW of Torts or the Wrongs Which Arise INDEPENDENT OF CONTRACT (Chicago, Callaghan \& Co., 2d ed. 1888) (1879).

16. Thomas M. Cooley, The General Principles of Constitutional Law in the Untred States of AMerica (1880).

17. See JONES, supra note 2 , at 247.

18. His then most recent publication, first issued in 1885, was a social and political history of his state. See Thomas M. Cooley, Michigan: A History of Governments (New York, Houghton, Mifflin \& Co., 3d ed. 1888) (1885). (1895).

19. The exception was Thomas M. Cooley, The Elements of Torrs (photo reprint 1995)

20. See Rogers, supra note 2, at 225-27 (describing Cooley's active lecturing during the 1880 s).

21. See JONES, supra note 2, at 295. 
the selection of commissioners to govern the railroads under the heretofore untested powers conferred on the new Interstate Commerce Commission. ${ }^{22} \mathrm{Coo}-$ ley had no interest in the appointment, but was importuned by President Cleveland to chair the Commission. ${ }^{23}$ Cleveland believed him to be perhaps the one person in America sufficiently disinterested to be trusted by all sides, and thus to give the Commission a viable chance of useful service. ${ }^{24}$ IIIness forced Cooley to leave the Commission in 1891,25 but his early leadership of that body provided significant guidance for the independent national administrative agencies established in ensuing decades.

In 1893, the American Bar Association graced itself by electing him its President. ${ }^{26}$ And over the next century, the Supreme Court of the United States cited Cooley's writings frequently, almost certainly more than those of any other legal writer. But these later events only underscored the eminence Cooley had already achieved by 1886 , an eminence that Harvard was almost bound to acknowledge.

\section{INTRODUCTION: COOLEY AT HARVARD}

The Harvard doctorate, appropriate though it was, caused a moment of tension. That tension signified changes in the American legal profession occurring at that moment. Those present honored both the declining populist-democratic aspirations of American law, represented by Cooley, and the rising technocratic-elitist pretensions of the profession, reflected in the emerging character of the Harvard Law School. More broadly, 1886 was a time when the enduring conflict between democracy and professionalism in the legal profession was being reordered by the secondary and tertiary effects of industrialization. The rising resolution effected at that time seemingly fit the needs, or at least the tastes, of an industrializing society. Whether that resolution fits the needs of a postindustrial society may be a question worthy of reflection. Possibly the populist traditions and values represented by Cooley will attract more adherence in the century to come than they have in the eleven decades that have passed since 1886.

In receiving his degree, Cooley acknowledged this tension. He spoke briefly at a dinner in Hemenway Gymnasium, along with Dean Langdell and Justice Holmes, then of the Supreme Judicial Court of Massachusetts. ${ }^{27}$ With appropriate modesty and grace, he saluted Harvard Law School for its great service to the nation and promise of greater service in the future-but he did so in terms unsettling to those present:

\footnotetext{
22. Cf. id. at 307-08 (describing the administrative discretion conferred on the Commission).

23. See id. at 305.

24. See id. at 306.

25. See id. at 340-4i (discussing Cooley's nervous breakdown and clinical depression).

26. Cooley served as president in 1894. See id. at 368. His presidential address is reported in 17 REPORTS OF AMERICAN BAR Association (1894) app. at 181.

27. See HARVARD, A Record of COMMEMORATION, supra note 1, at 65-89 (Dean Langdell's and Justice Holmes's addresses).
} 
[W]e fail to appreciate the dignity of our profession if we look for it either in profundity of learning or in forensic triumphs.... [1]ts reason for being must be found in the effective aid it renders to justice, and in the sense it gives of public security through its steady support of public order.

These are commonplaces, but the strength of the law lies in its commonplace character; and it becomes feeble and untrustworthy when it expresses something different from the common thoughts of men. ${ }^{28}$

That utterance stated a guiding premise of Cooley's celebrated professional career; it was a premise that shaped the mission of his law school, the character of his scholarship, and his judicial behavior. That premise was an axiom of American public law to most of those who professed and practiced it in the mid-nineteenth century. ${ }^{29}$ Nevertheless, Cooley's assertion of it at Harvard almost surely offended his host, Christopher Columbus Langdell, whose novel case-method teaching was on the verge of becoming the standard of a new professional elite. ${ }^{30}$ The remark so impressed Justice Holmes that he responded to Cooley on another occasion at Northwestern University in 1902, four years after Cooley's death. ${ }^{31}$

In 1886, Holmes was known to those present not only as a local judge, but as the author of The Common Law. ${ }^{32}$ Although destined for elevation to the Supreme Court of the United States, he would remain relatively obscure until his canonization in the 1920 s by some of the leaders of the newly emerging legal academy. ${ }^{33}$ Then, from our present perspective, he would come to overshadow Cooley and others as the most memorable lawyer of his time and as an intellectual patron to the newly emerging subprofession of academic law.

In this article I will briefly compare Cooley and Langdell as teachers, and Cooley and Holmes as judges, for the purpose of calling attention to ways in which technocratic elitism was transforming the legal profession. I will then examine some of Cooley's judicial opinions as illustrations of a professional

28. Id. at 95 .

29. However, public law became the domain of professional discourse in the late years of the Marshall Court; its emergence was marked by the publication of Joseph Story's Commentaries, which emphasized case law as a source of constitutional doctrine. See H. Jerperson Powel, THE MoRal Tradmion of AMERICAN CONSTTTUTIONALISM: A THEOLOGICAL INTERPRETATION 116-119 (1993) (discussing competing views of constitutional interpretation and the professionalization of legal argument in the 1830s); Maxwell Bloomfield, Law v. Politics: The Self-Image of the American Bar, 1830-1860, 12 AN. J. LEGAL HIST. 306, 307 (1968) (discussing competing conceptions of the role of law during the mid-nineteenth century).

30. See Harvard, A Record of Commemoration, supra note 1, at 84-87 (remarks of Professor Langdell); id. at 72-75 (remarks of Justice Holmes).

31. In his speech at Northwestern, Holmes acknowledged the power of Cooley's vision, and attempted to incorporate it into his own concept of the law:

It was affirmed, I believe, by a man not without deserved honor in his generation-the late

Chief Justice Cooley-that the law was and ought to be commonplace .... [T] The law may

keep its every-day character and yet be an object of understanding wonder and a field for the lightning of genius.

OlIVER WeNDEII Holdies, Address of Chief Justice Holmes at the Dedication of the Northwestern University Law School Building, Chicago, Oct. 20, 1902, in Collected Legal PAPERs 272, 276-77 (1920).

32. Oliver Wendeli holmes, JR., The Common law (Little, Brown \& Co. 1951) (1881).

33. See G. Edward White, The Canonization of Holmes and Brandeis: Epistemology and Judicial Reputations, 70 N.Y.U. L. REv. 576, 590 (1995). 
tradition that was being displaced and as manifestations of his efforts to express "the common thoughts of men."

\section{Harvard and the Rise of Technocratic Elitism}

The differences between Cooley and those he met in Cambridge were, of course, not all attributable to the fact that Cooley's conception of his roles as teacher and judge were formed in a pre-industrial society. There were also large subcultural differences resulting from geographical distance. Cooley's remark was not only unsettling to his audience in Hemenway Gymnasium, but would likely have been so to their forebears who had given rise and impetus to Harvard University, its law school, the leadership of Dean Langdell, and the judicial career of Holmes.

In 1886, Harvard was still a regional institution. It had been founded to train Puritan-Congregationalist ministers for the Massachusetts Bay colony, a defining mission that endured into the nineteenth century. ${ }^{34}$ Central to that Puritan faith was the dour Calvinist belief that most souls are doomed at birth. In the eighteenth century, the colony was still among the least tolerant places on earth; Quakers were not allowed to set foot there, and Baptists were driven into Rhode Island. ${ }^{35}$ Some Puritans became merchants and ship owners, and it was they who settled on Boston's Beacon Hill and lent support to Harvard.

Harvard's Puritan roots may partially account for the fact that it was the one established college in America that did not, in the years after the Revolution, commence teaching law as moral preparation for public life. Moral education was, to a true Puritan, unpromising: No mere schooling could be expected to alter God's plan. Moral teaching had, however, been established at William and Mary in 1779, and thereafter at Yale, Columbia, Princeton, Dartmouth, and numerous other institutions. ${ }^{36}$ But when at last Harvard opened its law school in 1817 , it was not presented as a service to the people or the republic, but as a program useful to students preparing themselves gainfully to serve private clients. ${ }^{37}$

However, that initial venture failed to attract an adequate paying clientele, and in 1829 Harvard Law School was reorganized around the services of Joseph Story ${ }^{38}$ to pursue the vision of a national service to the law pressed upon it by a Unitarian benefactor, Nathan Dane. ${ }^{39}$ Story's "Dane Law School" was more in keeping with programs of legal education at other colleges established

34. See Samuel Elior Morison, Three Centuries of Harvard, 1636-1936, at 23-24 (1936) (discussing how "[a] learned clergy was the immediate and pressing social need that Harvard was expected to fulfill").

35. For an account of the early years of the colony, see DAVID R. WIILIAMS, WIIDERNESS LOST: New ENGLAND In THE Jaws of AN ANGRY God (1982).

36. See Paul D. Carrington, The Revolutionary Idea of Legal Education, 31 WM. \& MARY L. REv. 527, 541-73 (1990).

37. See Arthur E. Sutherland, The Law at Harvard: A History of Ideas and Men, 18171967, at 54 (1967).

38. See id. at 79-86.

39. See id. at $92-100$. 
by such lawyers as Jefferson, Hamilton, Madison, and Clay, and sustained by such teachers as George Wythe and St. George Tucker. ${ }^{40}$

In Story's time, Harvard began to attract students from the South, but it was not until the arrival of Roscoe Pound in 1910 that the Law School appointed and permanently retained a law teacher who was not native to New England.41 William Kent had come from New York in 1846 and remained for a year;42 Nathaniel Holmes had come from Missouri in 1869 and remained for four; 43 William Keener, a Georgian practicing in New York, had come in 1883 and remained for seven. ${ }^{44}$ Everyone else associated with the Harvard Law School was decidedly a New Englander. Although it was still a current that ran deep in the institution, the Puritanical Calvinism had been muted and secularized.

This muting occurred in the first half of the nineteenth century. At that time, Beacon Hill and Harvard became centers of an intellectual community of admirable richness and depth. In 1815, in something like a coup, the governing board of Harvard was taken over by Unitarians; the University then participated fully in the "flowering of New England." 45 But New England it remained, and therefore not altogether American. In 1814, Massachusetts refused to supply troops for "Mr. Madison's War," and Harvard honored (and later employed) Isaac Parker, the judge who opined that the Governor had no legal duty to respond to the President's call for help. ${ }^{46}$ In 1815, a convention was held at Hartford to discuss the possibility of a New England secession, and it was attended by Massachusetts citizens. ${ }^{47}$ Perhaps it was Emerson who observed that at that time Europe still extended to the Alleghenies; indeed, Boston was depicted as then being as British as Edinburgh. ${ }^{48}$

The relative isolation of Boston from America was in part a consequence of economic forces. The building of canals in the early decades of the nineteenth century had tied the West to the ports of New York, Philadelphia, and Baltimore, leaving Boston, like Charleston, on an economic island, limited in its ability to participate in the spreading national economy. While its textile mills flourished, the movement of people, goods, and ideas across America was so

40. See Carrington, supra note 36, at 533-40; Paul D. Carrington, Teaching Law and Virtue at Transylvania University: The George Wythe Tradition in the Antebellum Years, 41 MERCER L. Rev. 673 (1990).

41. See SUTHERLAND, supra note 37 , at 236-39.

42. William, son of James Kent and a native of New York, served as Royall Professor for one year from 1846-47. See 2 Charies Warren, History of tHe HarVard LAW School AND OF EARLY LEGAL CONDITIONS IN AMERICA app. at 515 (1908).

43. See id.

44. See id. at 444 (describing the circumstances surrounding Keener's resignation); see also THE FOUNDATION FOR RESEARCH IN LEGAL HISTORY, A HISTORY OF THE SCHOOL OF LAW: COLUMBIA UNIVERSTTY 137-42 (Dwight C. Minor ed., 1955) (describing Keener's development of the casebook method) [hereinafter History of COLUMBIA LAW SchOOL].

45. See Van Wyck Brooks, The Flowering of New England (1936).

46. See Moruson, supra note 34, at 214. Harvard later appointed Judge Parker Royal a professor of law. See id. at 238.

47. The proposal was advanced by John Lowell. See Samuel Eliot Morison, Dissent in the War of 1812 , in Dissent in Three AMerican Wars 18-26 (1970). Timothy Pickering promoted New England secession as early as 1803 . See Ferris Greenslet, The Lowelis and THEIR SeVEn WorLds 135-136 (1946).

48. See Brooks, supra note 45 , at $7,10$. 
latitudinal that the New England economy shrank in relation to those in the mid-Atlantic and western sections of the nation.

Perhaps the economic isolation stimulated, or at least sheltered, the haughty self-assurance of the New England elite. Even well-informed Bostonians were disinclined to notice events west of the Connecticut River. Boston's claim to cultural superiority was unmitigated by modesty. Emerson put the matter bluntly. "I do not speak with any fondness," he said, "but the language of coldest history, when I say that Boston commands attention as the town which was appointed in the destiny of nations to lead the civilization of North America." 49

This self-assurance had a large moral dimension attributable to the Puritan tradition of severe moral judgment, such as that suffered by Nathaniel Hawthorne's memorable Hester Prynne in The Scarlet Letter. Bostonians found it especially easy to detect the moral failings of others. This was most evident in the emergence of the abolition movement in Boston during the antebellum years. Although there were emancipationists and abolitionists in the western states, there was an exceptional moral arrogance in the expressions of abolitionist sentiment by Bostonians such as Wendell Phillips, Willam Lloyd Garrison, and Charles Sumner. Although early residents of Beacon Hill had benefitted unblushingly from the slave trade, many of their descendants felt no compassion for the moral plight of Southern slaveowners. Rather, abolitionist Bostonians denounced that entire population as among the most morally degraded persons on earth, a feeling that was of course reciprocated. Harriet Martineau, an English visitor in the 1830s, was appalled by the livid hatred between these two groups. ${ }^{50}$

This secular Calvinism had dimensions other than the demonization of the South. For instance, its success in the Civil War led Calvinism's adherents to more reformist efforts premised on the moral and intellectual superiority of an elite. In the years following the Civil War, Boston became the center of the American Social Science Association ("ASSA"). ${ }^{51}$ Founded by former abolitionists, it became an organization of "gentry intellectuals" who aimed to employ social science as an engine of social reform. ${ }^{52}$ They sought to make America "an earthly paradise" 53 by reforming prisons, stirring the poor to take better care of themselves, eliminating prostitution and intemperance, prompting the construction of libraries and savings banks, and achieving a score of other triumphs of comparable dimension over the degraded persons populating the

49. Id. at $97 \mathrm{n} .8$ (quoting Ralph Waldo Emerson, The Natural, History of INTEllect and OTHer Papers (1904)).

50. See Harriet Martineau, Soctety in America 119-22 (Seymore Martin Lipset ed., Peter Smith 1968) (1837).

51. See generally Mary O. Furner, AdVocacy and ObJectivity: A CRisis in the Professionalization of American Soctal Science, 1865-1905, at 28-29 (1975); ThOMas L. Haskeil, The Emergence of Professional Social Science: The American Social Science Association and the Nineteenth-Century Crisis of Authority (1977); Dorothy Ross, The Origins of American SOCIAL SCIENCE (1991).

52. Dorothy Ross referred to ASSA as gentry intellectuals. See Ross, supra note 51, at 63.

53. "Earthly paradise" was the goal stated by Daniel Coit Gilman in his presidential address. D.C. Gilman, Annual Address of the President, J. Soc. Scr., Dec. 1879, at 1. 
lower classes and the lesser regions of the nation. ${ }^{54}$ Buoyed by these goals, the Association was near its zenith in 1886.

Moreover, Boston's traditional smugness was reinforced by the effect of industrialization on American society. By 1886, academic credentials, which had been of little value in antebellum America, were in rapidly growing demand. The idea of division of labor central to industrialization seemed to promise the satisfaction of all human wants. Persons of talent and ambition sought to have their competence certified, partly for economic reasons and partly for social status. As the demand for certification of qualifications gave rise to a boom in higher education, universities became the factories of human capitalism. Old professions competed for academic ornamentation, and new ones were established to meet the demand for professional status. No institution was better situated to respond to this demand than Harvard. Not only was it the oldest college in North America, but it was draped in the "old-money" pretensions of Beacon Hill. On that account, Harvard was the ready center of the technocratic elitism emerging in the legal profession in 1886.

Thus, when Cooley received his degree, Boston's elite and Harvard were as self-assured as ever. Although their Puritanism had been secularized, it was prospering. Their claim to elite status rested not on predestined moral worth, nor on great fortunes such as those being amassed elsewhere, but on their intellectual dessert. Their superiority was in at least some measure real, for Emerson's hyperbole contained a kernel of truth. An exceptional number of highly literate and prudent persons resided on Beacon Hill and in its environs. ${ }^{55}$ The institution of slavery, if not every individual caught in its web, certainly merited their odium. The American Social Science Association had admirable aims and some useful if still half-baked ideas. And Boston was a hub, not only of New England, but of the flowering of elite higher education in America.

Langdell and Holmes manifested that flowering in different ways, marking each for contrast with Cooley. In 1886, Langdell was the prophet of the credentialism in American legal education soon to become the instrument of social and economic elitism in the American bar. Holmes was the prophet of intellectual elitism in the American legal academy. It is worth noting that Langdell and Holmes were not in league with one another in these roles. Indeed, there was perhaps as much tension between Holmes and Langdell as between either of them and Cooley. ${ }^{56}$ Nevertheless, Cooley represented a profession that consciously sought to express the moral values and emerging aspirations of a classless, self-governing people. Such a profession was not a congenial venue for either Langdell or Holmes.

54. For a discussion of the goals of the Association in its formative years, see HASKel, supra note 51 , at $100-10$.

55. For a cultural history of nineteenth century Boston, see MARTtN Green, The Problem of Boston: SoMie Readings in Social History (1966).

56. For a discussion of Holmes's view of Langdell, see MARK Dewolfe Howe, Justice Oltver Wenderl Holmies: The Proving Years 1870-1882, at 155-59 (1963). 


\section{The Origins of Thomas Cooley}

The culture from which Thomas Cooley emerged was in important respects the antithesis of Beacon Hill. He had come a very long way to stand at the rostrum of honor in Hemenway Gymnasium that fall evening.

Four Cooley brothers left their father's Massachusetts farm in 1800 for the Genesee region of New York not long after the area had been populated predominantly by Iroquois. ${ }^{57}$ They were among many immigrants to New York from New England. In 1808, Mortimer Cooley laid out his farm on a hill west of the town of Rochester, near the village of Attica. There, he was able to provide subsistence, but little more of material value, for his very large family. ${ }^{58}$ Thomas Cooley later recorded the lives of such pioneer farmers:

A rude log cabin for a home, and the bare necessaries of life for their families contented them while they were clearing their lands; and the lessons of industry and economy would have been forced upon them by the situation even if they had not learned them before, as the most of them had. . . . [H]ard labor and the chills of fever incident to the clearing of a new country gave them sallow complexions and made them prematurely old; but in coming [West] ... they had calculated not so much upon their own immediate advantage as upon giving their children an opportunity "to grow up with the country"; and they accomplished all they had counted on if they could see that year by year their possessions increased in value, and could rely with confidence upon giving their children the rudiments of education and a fair start in the world, and on being independent in their circumstances in their old age. Even now, though they could not supply all their wants from their farms, they contracted few debts, but postponed purchases when they had nothing to barter for the articles they desired. ${ }^{59}$

Despite all this noble personal sacrifice, the social order created by men like Mortimer Cooley was reviled by socially elevated observers from the settled, Puritan realm east of the Hudson River, who thought that moral and religious degradation pervaded western New York. While here and there he found a village resembling admirable old New England, ${ }^{60}$ James Kent, the Chancellor of New York, "pronounced whole communities immoral."61 Yale President Timothy Dwight toured the state and concluded:

Together with a collection of discreet and virtuous people, there is sometimes [in upstate New York] an unhappy proportion of loose, lazy, shiftless, and unprincipled inhabitants ....

... Too ignorant ... to discern in what the real respectability ... consists, and too vicious willingly to adopt what is excellent ... they employ themselves

57. See Jones, supra note 2, at 5-6.

58. See id. at 7-8.

59. COOLEY, supra note 18 , at $240-41$. The description is of Michigan in the 1830 s, but he was telling the story of immigrants from New York and Ohio whose ancestors were from New England, and the account is indirectly autobiographical.

60. James Kent, riding circuit, was especially attracted to Canandaigua, where the Cooleys resided between 1800 and 1808. See John TheOdore Horton, JAMES Kent: A Study in Conservatism 17631847 , at $130-33$ (1939).

61. Id. at 126 . He was especially offended by the number of Jeffersonian Democrats he found in New York. See id. 
in copying the fashions, follies, and vices of cities. To be first, and excessive in fashions; to make a parade in the midst of poverty; to be pert; to gamble; to haunt taverns; to drink; to swear; to read newspapers; to talk on political subjects; to manage the affairs of the nation and neglect their own; to profess themselves infidels; to seem to know everything and plainly to care nothing about religion; to array themselves against its ministers, its friends, and its interests; and to be wiser in their own conceit than seven men who can render $a$ reason are strong features of the character of such men. ${ }^{62}$

Even the more tolerant adherents of Thomas Jefferson found cause for objection in what they saw. In the years when Mortimer Cooley was first breaking sod, the most popular American novel was written in neighboring Pittsburgh by an ardent Jeffersonian: lawyer, judge, and former Presbyterian minister Hugh Henry Brackenridge, who had practiced among the early settlers in western Pennsylvania. ${ }^{63}$ His Modern Chivalry ${ }^{64}$ was a satire ridiculing the ignorance and venality of his fellow pioneers. The novel's antihero was a greedy, unlettered Irish immigrant who sought and received from the frontier citizenry unmerited advancements resulting inevitably in disgrace for himself and in misery for the public at large. He depicted as quixotic the idea that ordinary citizens, unguided by wiser heads, are capable of governing themselves.

A few years later, another Jeffersonian novelist, James Fenimore Cooper, 65 returned home to upstate New York after an extended sojourn in Europe to find cause for deep concern about the fate of the republic.66 While pleading with fellow citizens to regain the public virtue that had been manifest in the War of Independence, Cooper in his fiction depicted lawyers not as leading practitioners of public virtue, but as self-seeking and cunning pettifoggers. ${ }^{67}$ The an-

62. 4 Timothy Dwght, Travels in New England and New York 3-4 (Barbara Miller Solomon ed., Harvard Univ. Press 1969) (1822). The letter describes Dwight's impressions of the region during a trip taken in the fall of 1804 . President Dwight was apparently given to such jeremiads. See LaWreNCe M. Friedman, A History of AMERICAN LAW 183 (1973).

63. See generally 1 HenRy AdaMis, History of the Unted States of America 124-25 (New York, C. Scribner's Sons 1890); JoSEPH J. ELIIS, AFIER THE REvolution (1979) (identifying the changing social conditions and values of revolutionary America through the stories of four men whose lives grew out of that social context); Claude Milton Newlin, The Life and Writings of Hugh Henri Brackenridge (1932); Henr. Petter, The Early Amierican Novel 87-165 (1971); Madeline Sapienza, Modern Chivalry in American Law: H.H. Brackenridge's Legal Thought (1992).

64. H.H. Brackenridge, Modern ChIvalRy (Claude M. Newlin ed., 1937). The work first appeared in serial form in Philadelphia from 1792 to 1814. For an encapsulation of Brackenridge's views, see Paul D. Carrington, Law and Chivalry: An Exhortation from The Spirit of the Hon. Hugh Henry Brackenridge (1748-1816), 53 U. PrTt. L. Rev. 705 (1992). For a critical assessment of the novel, see Robert A. Ferguson, Law and letters in AMerican Culture 119-28 (1984).

65. Cooper identified himself as an "American who wishes to illustrate and enforce the peculiar principles of his own country, by the agency of polite literature." J. FENMMORE-COOPER, A LETTER ro His CoUNTRYMren 98 (New York, John Wiley 1834).

66. While traveling abroad, Cooper boasted of American republican traditions and the social order established here. See, e.g., JAMEs Fenimore Cooper, Notions of Americans: Picked Up By A TravELING BACHeL OR (James Franklin Beard, James P. Elliot \& Lance Schachterle eds., State Univ. of N.Y. Press 1991) (1828); Letter from James F. Cooper to General Lafayette (Aug. 10, 1833), in 2 THE LETters and Journals of James Fentmore Cooper 122 (James Franklin Beard ed., 1960).

67. See FERGuson, supra note 64 , at 300 . 
tihero of the novel Home as Found ${ }^{68}$ was a status-hungry lawyer who is proud to be American, but has no idea of any obligations that this entails. In that work, Cooper expressed the fear that America was crashing, and decried the leveling process that was displacing the rules of social propriety. ${ }^{69}$

Perhaps in manifestation of the social conditions observed by Kent, Dwight, Brackenridge, and Cooper, upstate New York was in the early decades of the nineteenth century a center for religious revivalism. ${ }^{70}$ Mormonism emerged not far from Attica, ${ }^{71}$ as did a dozen Protestant denominations now forgotten. ${ }^{72}$ A likely cause of this religious activity was a reaction of citizens against the moral and intellectual arrogance of the traditional Congregational and Presbyterian clergies, an arrogance reflected in the observations of Dwight and Brackenridge, both of whom were former ministers of those traditional Calvinist faiths. The Anti-Masonic movement also had its origins nearby, ${ }^{73}$ revealing hostilities to a different form of moral pretension.

Among the most influential new faiths was the modified Puritanism of a revivalist minister, Charles Grandison Finney of Utica. ${ }^{74}$ In "plain and pungent" language, ${ }^{75}$ he taught that damnation was not so predestined as traditional Puritans supposed, but could be avoided by firm acts of will that resulted in a morally correct life. ${ }^{76}$ Everyman, he taught, was responsible for his own moral fate. ${ }^{77}$ This spiritual independence was a better fit with the political sentiments of those who had participated in the Revolutionary War than was the fatalism of Puritan New England. ${ }^{78}$

\footnotetext{
68. 1 \& 2 J. FenIMORE-COOPER, Home As Found (Lea \& Blanchard 1938) (1854).

69. See 2 id. at 12 .

70. See generally Whitney N. Cross, The Burnt-Over District: The Social and IntellectUAL History of ENthusiastic Retigion in Western New York, 1800-1850 (1950) (describing the religious character of western New York and the religious forces that drove social movements in the region).

71. The gold plates recording the Book of Mormon were reportedly discovered by Joseph Smith as a result of a vision he experienced on a farm near Rochester and reported in 1830. See Thomas F. O'Dea, The Mormons 3-4 (1957).

72. For an account of the emergence of Protestant denominations in western New York, see CRoss, supra note 70 , at $173-208$.

73. See generally id. at 113-25 (surveying the genesis of the Anti-Masonic movement in western New York). In 1826, William Morgan was abducted from his home in Batavia, New York and apparently murdered. Shortly after Morgan's disappearance, there appeared in print an incomplete book purportedly authored by him and revealing supposed secrets of the Masons. It was widely believed that he had been murdered by Masons to prevent completion of his work and the exposure of lodge secrets. See O'DEA, supra note 71, at 11. The Anti-Masonic Party resulted, and was a factor in New York politics for a decade. See id. at 35.

74. See Harris Elwood Starr, Charles Grandison Finney, in 6 Dictionary of AMERICAN BIograPHY 394 (Allen Johnson \& Dumas Malone eds., 1931).

75. 1 Robert Samuel Fletcher, A History of Oberlin College: From Its Foundations Through tHe CiviL War 11 (1943).

76. See CROss, supra note 70, at 27 (noting that Finney's theology leaned "away from the notion of predestination and toward free will"). Finney's special doctrine was immediatism, a doctrine bearing on the consequences of sin for the human soul. See id.

77. This antielitist doctrine was sometimes referred to as the Second Awakening of Calvinists. On its relation to the antislavery movement, see J. David Greenstone, The Lincoln Persuasion: RemakING AMERICAN LIBERALISM 260-62 (1993).

78. Similar thoughts were also expressed in England and on the continent. Indeed, Finney's emphasis on individual consciousness and free will resembles ideas being expressed in Germany by Im-
} 
These settlers of upstate New York were among the first to identify themselves as citizens of a nation as well as a state. People who crossed the mountains, unlike those who remained in Massachusetts, mingled with Irish and Germans and others to form a different collective consciousness. They expected their children to marry spouses of varying ancestries and to move further west. So it was that the Cooley brothers renounced their fealty to Massachusetts and replaced it with a sense of belonging to a much larger space, one of continental dimensions.

Among the distinctive features of their emergent national culture was a widely shared preoccupation with law and politics that departed from antecedent Puritan traditions. ${ }^{79}$ The novelty of self-government called many to politics, and the unique bonding of politics to law effected by the Philadelphia Convention of 1787 elevated the visibility of legal institutions. These institutions were largely new or newly recognized as belonging to the people. The observations of such European travelers as Alexis de Tocqueville ${ }^{80}$ and Harriet Martineau ${ }^{81}$ merely confirmed in the locals their shared sense of themselves as a people devoted to law and politics. ${ }^{82}$ However, this preoccupation with politics did not reflect unbounded trust in the wisdom of the people. As de Tocqueville observed, their politicians, like those of later times, were fawning sycophants, even more given to groveling to the electorate than were the oiliest courtiers in Europe in their submissions to monarchs. ${ }^{83}$ Democracy was favored less out of regard for the popular or conventional wisdom than out of disregard for the wisdom of the elite, who put themselves forward as political or intellectual leaders or as religious or moral guardians.

There was thus a political and legal subtext to the revivalism celebrating Everyman's responsibility for his own fate. Suspicion of the pretensions of "learned" professions was widespread among these citizen-revivalists. The causes of temperance, pacifism, suffrage, prison reform, women's rights, and especially opposition to slavery (keen among the struggling farmers of upstate New York) all gained support. ${ }^{84}$ Not many were prepared to follow William Lloyd Garrison and dissolve the federal union to rid themselves of cocitizenship with despised slaveowners, ${ }^{85}$ nor were many yet prepared to wage a war

manuel Kant, though Kant's writing was not widely circulated in upstate New York. See, e.g., Indanuel Kant, Metaphysical Elemients of Justice: Part I of the Metaphysics of Morals (John Ladd trans., Bobbs-Merrill 1965) (1797).

79. See 1 Alexis de Tocouevile, Democracy in America 247-53 (Henry Reeve \& Francis Bowen trans., Philips Bradley ed., Alfred A. Knopf 1989) (1835).

80. See id. at 199-253.

81. See 3 Harriet Martineau, Retrospect of Western Travels (London, Saunders \& Otley 1838) (recounting her travels through America and noting throughout the unique characteristic of local initiative and participation).

82. A joke of the time had two thirsty Americans having a chance meeting on the Sahara; they promptly held an election.

83. See 1 TOCQUEVILLE, supra note 79 , at 267-68.

84. See, e.g., Cross, supra note 70, at 211-37 (discussing revivalist reform politics in Western New York).

85. For an account of Garrison's activity in the 1830s and 1840s, see JoHN JAY CHAPMAN, WILliam Lloyd Garrison 34-157 (1921); John L. Thomas, The Liberator: William Lloyd Garrison, A Blography 114-366 (1963); Ronald G. Walters, The ANTISLAVery Appeal: American Aboli- 
over the issue. Still, their intention to rid their new republic of the moral blight was absolute. ${ }^{86}$

The first national political leader to emerge from this culture was Martin Van Buren, New York governor and later, President. ${ }^{87}$ Adherents of the political culture Van Buren represented were sometimes known as Barnburners because they were said to be willing to burn their barns to kill the rats residing in them. ${ }^{88}$ Their favorite political writer was the editorialist William Leggett, ${ }^{89}$ and it was he who was perhaps the most articulate exponent of the Barnburners' doctrine of "equal rights" as one requiring "free labor, free schools, free trade, and free speech." 90

Barnburners held simple views on matters of political economy. Leggett, for instance, voiced the position that government was inevitably and shamelessly committed to "bankers and others, who choose to live in idleness by their wits rather than earn an honest livelihood . ..."91 Barnburners often cited Jefferson's dictum that government should leave men "free to regulate their own pursuits of industry and improvement, and shall not take from the mouth of labor the bread it has earned." 92 Second only to the Declaration of Independence was the Barnburners' emphasis on the 1830 message of Andrew Jackson that accompanied his veto of the renewal of the charter of the Bank of the United States:

TIONISM AFTER 1830, at 3-18 (1976). Frederick Douglas was quick to see that Garrison's program of abolition by disunion would do nothing to end the suffering of slaves. See Frederick Douglas, The AntiSlavery Movement, in SLAVERY AtTACKed: THE ABOLITIONIST CRUSADE 126-127, 331 (John L. Thomas ed., 1965).

86. In this, they applauded Daniel Webster's second speech in reply to Senator Hayne. See Daniel Webster, Second Speech in Foot's Resolution, in 3 THE WORKS OF DaNiel WeBster 270 (Boston, Little, Brown \& Co. 1860).

87. See Arthur M. Schlesinger, Jr., The Age of Jackson 50, 261-62 (1945).

88. They formally called themselves the Equal Rights Party. See Richard Hofstadter, William Leggett, Spokesman of Jacksonian Democracy, 58 PoL. SCI. Q. 581,588 (1943). I avoid the use of that term as misleading to contemporary readers. The Whig press of the day referred to them as Locofocos. That term, used also to refer to friction matches that had recently been invented, called attention to the sometimes riotous character of their meetings, which were on occasions calmed by turning off the gas lights. See SCHLESINGER, supra note 87, at 191-92. Although this term is now often used by historians, I find it less agreeable and surely less descriptive to contemporary readers than "Bamburner," a term that appeared later but was applied to substantially the same people who constituted the Equal Rights Party. See id. at 398.

89. See Hofstadter, supra note 88 , at 582; see also Marvin Meyers, The Jacksonian PersuaSION: PoltTICS AND BELIEF 185 (2d ed. 1960); Lester Harvey Rifkin, William Leggett: Journalist-Philosopher of Agrarian Democracy in New York, 32 N.Y. HIST. 45 (1951). Leggett was born in New York City in 1802. He was a seaman, poet, and theater critic before becoming the editorialist for the Evening Post, which he owned with William Cullen Bryant. He died in 1839. His friend and admirer, Theodore Sedgwick, Jr., promptly collected and published his work in 1 \& 2 A Collection of Polmital WritINGS OF WILLIAM LEGGETT (Theodore Sedgwick, Jr. ed., Amo Press 1970) (1840) [hereinafter Polit-

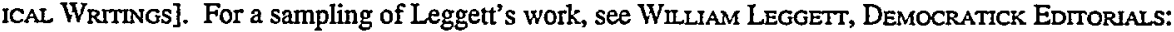
Essays In Jacksontan Political Economy (Lawrence H. White ed., 1984) [hereinafter LeggetT, DEMOCRATICK EDITORIALS].

90. Free speech in this context centered on freedom of religious expression. Leggett resisted all forms of religious intolerance, perhaps especially anti-Catholicism, which was at the time the most common form of intolerance. See LeGgett, Democratick Editorials, supra note 89, at 21.

91. Id. at 255 .

92. First Inaugural Address (Mar. 4, 1801) in 8 The Writings of Thomas Jerferson 1, 4 (Paul Leicester Ford ed., New York, G. P. Putnam \& Sons 1897). 
It is to be regretted that the rich and powerful too often bend the acts of government to their selfish purposes. . . . [W] hen the laws undertake to add to [their] natural and just advantages artificial distinctions, to grant titles, gratuities, and exclusive privileges, to make the rich richer and the potent more powerful, the humble members of society-the farmers, mechanics, and laborerswho have neither the time nor the means of securing like favors to themselves, have a right to complain of the injustice of their Government. There are no necessary evils in government. Its evils exist only in its abuses. If it would confine itself to equal protection, and, as Heaven does its rain, shower its favors alike on the high and the low, the rich and the poor, it would be an unqualified blessing. 93

Mistrust of government intervention was the Barnburners' reaction against eighteenth century mercantilism, vestiges of which remained in the economic regulation that reigned in much of antebellum America. This regulation was refiected in myriad local laws that controlled trade to the advantage of men of commerce. 94 They united in opposition to the protective tariff that raised the price of textiles and farm implements that subsistence farmers required, ${ }^{95} \mathrm{a}$ tariff central to the economic policy of their Whig rivals. ${ }^{96}$ As Jacksonian Democrats, they sternly opposed public facilitation of the aggregation of private wealth through monopolies, charters, licenses, and other privileges granted to corporations that endorsed mercantilist economic theories.97 Barnburners' convictions were redoubled when the depression of 1837 to 1843 triggered a bank panic. They regarded these events as the inevitable consequence of government intervention to support the efforts of some citizens to gain wealth quickly and easily. ${ }^{98}$

William Leggett clearly expressed how the political convictions of the Barnburners related to the so-called learned professions:

Take a hundred ploughmen promiscuously from their fields, and a hundred merchants from their desks, and what man, regarding the true dignity of his

93. Andrew Jackson, Veto Message (July 10, 1832), in 2 A Compllation of tHE Messages AND Papers of the Presments: 1789-1897, at 576, 590 (James D. Richardson ed., Washington, D.C., Gov. Printing Office 1896).

94. See William J. Novak, Public Economy and the Well-Ordered Market: Law and Economic Regulation in 19th-Century America, 18 L. \& Soc. InQuiry 1, 1-3 (1993).

95. The Jacksonian position on economic regulation was set forth at length in 1-3 THEODORE Sedgwick, Public and Private Economy (New York, Harper \& Bros. 1836). Adam Smith's work, from which laissez faire economics drew expression, was likewise a reaction against the protectionist mercantilism practiced in eighteenth century England. See, e.g., ADAM SMTrH, AN INoutRY INTO THE Nature and Causes of the Wealth of Nations (Edwin Cannan ed., Random House 1937) (1776). Smith was himself no social Darwinist or eulogist for unrestrained predation by wealth. See Jacob Viner, Adam Smith, in 14 INTERNATIONAL ENCyClopedia of the SOCial SCIENCEs 322, 327 (David L. Sills ed., 1968).

96. The Whigs, led by Henry Clay, long favored "The American System," a scheme to collect a protectionist tariff that would provide the revenue for internal improvements such as roads and canals. For a brief description of this scheme, see MerRII D. Peterson, The Great Truumvirate: Webster, Clay, and CALHOUN 68-84 (1987).

97. In its more extreme forms voiced by Leggett, this position resisted public asylums for the insane and pensions for Revolutionary War veterans; it also favored privatization of West Point and state prisons. See LegGetr, Democratick Edrtorials, supra note 89, at 42, 289-92, 296, 315.

98. See generally Samuel Rezneck, The Social History of an American Depression, 1837-1843, 40 AM. Hist. REv. 662 (1935) (discussing the sudden and catastrophic effects of the Depression). 
nature, could hesitate to give the award of superior excellence, in every main intellectual, physical, and moral respect, to the band of hardy rustics, over that of the lank and sallow accountants, worn out with the sordid anxieties of traffic and the calculations of gain? ${ }^{99}$

In accordance with this view, Barnburners dismantled ramparts of privilege wherever they gained power, and often first among the privileged regulatory protections stripped away were licensing requirements in medicine and law. ${ }^{100}$

In most states, the Barnburners succeeded in eliminating apprenticeship requirements for admission to the bar ${ }^{101}$ _barriers which were thought necessary to assure the quality of professional services. In the English tradition, as Lord Coke had expressed it, "[c]auses which concern the life, or inheritance, or goods, or fortunes of his subjects, are not to be decided by natural reason, but by the artificial reason and judgment of law, which ... requires long study and experience, before that a man can attain to the cognizance of it."102 The Jacksonian view, on the other hand, was that such entry requirements erecting a structure of "artificial reason" disadvantaged the working poor. For this reason, the Indiana Constitution of 1850 guaranteed to every citizen of good moral character the right to practice law. ${ }^{103}$ Although the bar of New York managed for a time to maintain control of admission to the legal profession, ${ }^{104}$ the Jacksonians, led by David Dudley Field, achieved success by drafting the New York Constitution of 1846 to deprive the professions of power to control the admission of their members. ${ }^{105}$ Only Massachusetts continued to require a longer period of apprenticeship. ${ }^{106}$

Barnburners also advocated the election of judges. This reform was a reaction against the elitist arrogance of colonial and post-colonial judges. ${ }^{107}$ Their stated purposes in electing judges was to strengthen the courts as a constitutional bulwark against the abuse of power by legislatures and executives. ${ }^{108}$

99. Leggert, The Inequality of Human Condition, in Poltrical WrIINGS, supra note 89, at 164. 100. See Paul Starr, The Social Transformation of American Medicine: The Rise of A Sovereign Profession and The Making of A Vast Industry 57 (1982).

101. See id; see also Maxwell Bloompield, American Lawyers in a Changing Society, 1776-1876, at 32-58 (1976) (discussing antilawyer sentiment in the early republic); SAMUEL HABER, The Quest for Authorty and Honor in the American Professions 1750-1900, at 91-116 (1991) (discussing the egalitarian movement from 1830 to 1880 ).

102. Prohibitions del Roy, in 7 The RePORTS of SIR Edward COKE pt. 12, at 63, 65 (George Wilson ed., London, J. Rivington \& Sons 1777).

103. IND. Const. of 1851, art. VII, § 21. (1965).

104. See Anton Herman-Chroust, The Rise of the Legal Profession in America 245

105. The New York legislature retained apprenticeship as an alternative to formal education, but soon awarded "diploma privileges" to Hamilton, Albany, N.Y.U., and Columbia, exempting graduates of those schools from examination requirements. See History of Columbia Law School, supra note 44 , at $52-53,104-08$.

106. Even in Massachusetts, local bar organizations were dissolved. See Gerard W. Gawalt, Massachusetts Lawyers: A Historical Analysis of the Process of Professionalization, 1760-1840, at 145 (1976) (unpublished Ph.D. dissertation, Clark University (Worchester, Mass.)) (on microfilm with the Stanford Law School).

107. See Evan Haynes, The Selection and Tenure of Judges $96-97$ (1944) (discussing political favoritism in judicial appointments after the Revolution and the resentment thereby engendered).

108. The best statement of the case for the election of judges may be FREDERICK GRIMKE, THE Nature AND TendenCy of Free Institutions 438-75 (John William Ward ed., 1968). 
Elected judges were presumed to have a stronger claim to political status than mere appointees. Moreover, accountability to the electorate was thought to be both an inducement to responsible performance of public duty and an assurance that the courts would interpret legal texts to reflect the values of the people, not their own eccentric preferences or those of a professional elite. ${ }^{109}$ This reform was first adopted for all its judges by Mississippi in 1832; New York followed in 1846, and by 1860 most American states had adopted or amended their constitutions to provide for the election of judges. ${ }^{110}$

Although sometimes accused of kinship with the Jacobins, who authored the reign of terror in France, the Barnburners were not Marxists resentful of economic class distinctions. ${ }^{111}$ They did not object to the honest accumulation of wealth by means of private initiative and they made no claim against wealth so produced in enterprises unsubsidized by public revenue or exactions on the working poor. Their economic views paralleled their religious beliefs as neoCalvinists, placing responsibility on each man for the welfare of himself and his family. In this they shared the sentiment of Carlyle, their Victorian contemporary, that work of almost any kind is morally redemptive. "Know thy work and do it,"112 was the injunction they asked all to obey.

Upstate New York was tied to the infant western frontier by 1818 , when steamboats appeared on Lake Erie. Children of the first settlers of western New York were soon after laying out farms in northern Ohio. The Erie Canal was completed in 1825 , when Thomas Cooley was one year old. The canal made New York a world-class city, and set Rochester and Buffalo on the path to becoming metropolitan centers. In ensuing decades, it also propelled the stream of migrants to northern Ohio and southern Michigan. These migrants were joined by nineteen-year-old Cooley, who arrived in the village of Adrian in 1843 , to commence his career.

\section{CoOley aNd LANGDELl}

The law school Cooley led from 1858 to 1883 was quite different from Langdell's, perhaps as different as Attica and Adrian were from Beacon Hill.

Many Jacksonians imbued with the spirit of the equal rights doctrine opposed higher education altogether. Hugh Henry Brackenridge's satire depicts frontiersmen feeling deep shame if suspected of reading a book. ${ }^{113}$ Kentucky

109. For an account of elected judges in Cooley's time, see Kermit L. Hall, Constitutional Machinery and Judicial Professionalism: The Careers of Midwestern State Appellate Court Judges, 18611899, in The New High PrIEsts: Lawyers In Post-Civil War America 29 (Gerard W. Gawalt ed., 1984). See also Kermit L. Hall, The "Route to Hell" Retraced: The Impact of Popular Election on the Southern Appellate Judiciary, 1832-1920, in Ambivalent Legacy: A Legal History OF THE SoUTH 229 (David J. Bodenhamer \& James W. Ely, Jr. eds., 1984) (evaluating the quality of popularly elected judges in the South).

110. See HAYNes, supra note 107 , at 101-35.

111. See Louns Hartz, The Liberal Tradition in America: An InTERpretation of AMErican Polmical Thought Since the Revolution 89 (1955) (arguing that the two conflicting national impulses that dominated the Jeffersonian and Jacksonian eras, capitalism and democratic egalitarianism, respectively, should have supplemented each other rather than sparked political confrontation).

112. Thomas Carlyze, Past and Present 202 (Oxford Univ. Press 1960) (1909).

113. See BrackenRIDGE, supra note 64 , at 419. 
Governor Joseph Desha, in the same spirit, eliminated the small state subsidy to Transylvania University, protesting that the state had "lavished her money for the benefit of the rich, to the exclusion of the poor; and that the only result is to add to the aristocracy of wealth, the advantage of superior knowledge."114 In 1834, the Indiana legislature proposed to require both faculty and students at Indiana University to engage in manual labor, such as tree cutting (then the chief pastime in the state) as a corrective for their patrician leanings. ${ }^{115}$ Four decades later, the same legislature abolished the University's law and medical schools, reporting that it was "'no duty of the people to help men into these easy professions." "116

Nevertheless, hostility to higher education was not an essential feature of "equal rights" politics. Some New York Barnburners engaged in developing colleges, universities, and even law schools. The law departments at New York University, Hamilton College, Oberlin College, and the University of Michigan were all Jacksonian in their origins. Indeed, many state universities in Wisconsin and the states west of the Mississippi were established on the Michigan model, ${ }^{117}$ as was the Cornell Law School. ${ }^{118}$

The Jacksonian tradition in higher education seems to have originated in 1829, when a distinguished group of New York City Democrats, known for a time as "The Club,"119 gathered to establish the institution that later became New York University. The group was dissatisfied with the classical, patrician, and Episcopal bents of Columbia College. They were mindful of the establishment in 1828 of the University of London, ${ }^{120}$ which aimed to provide useful instruction for young men of the emerging English middle class, ${ }^{121}$ and of the rising standards of German universities. ${ }^{122}$ Even more, perhaps, they were attentive to the 1828 election of Andrew Jackson, which demonstrated that political power in the United States had passed from the social elite. As one member of The Club explained, it appeared "impossible to preserve our democratic institutions and the right of universal suffrage unless we could raise the

114. Letter from Theodore W. Clay to Henry Clay (Nov. 11, 1825), in 4 THE PAPERS OF Henrs CLAY 816, 818 n.4 (James F. Hopkins ed., 1972) (quoting Governor Joseph Desha). (1940).

115. See JaMes AlBert WOOdBuRn, History OF Indiana UnIVERSITY, 1820-1902, at 107-08

116. Id. at 280-81 (citing David Starr Jordan, The Days of A MAN 145 (1922)).

117. See Paul D. Carrington, Legal Education for the People: Populism and Civic Virtue, 43 U. Kan. L. Rev. 1 (1994); Paul D. Carrington, Teaching Law in the Antebellum Northwest, 23 U. ToL. L. REv. 3 (1992); Paul D. Carrington, Law and the Wisconsin Idea (unpublished manuscript on file with author).

118. The first two presidents of Comell, Andrew Dickson White and Charles Kendall Adams, were Michigan colleagues of Cooley. Adams' plan for a law school reflected the Michigan tradition. See Cornell UNIVERstTy, Report of the Special Commrtree on the Establishment of a DepartMENT OF LAw (1886). The founding dean at Cornell was Harry Burns Hutchins, who came from Michigan and later returned to Ann Arbor. See Harry B. Hutchins, The Cornell University School of Law, 1 Green BAG 473 (1889).

119. For a description of "The Club," see John Austin Stevens, Albert Gallatin 379-80 (Boston, Houghton, Mifflin \& Co. 1884).

120. See THeOdoRe F. JONES, New YoRK UNTVERSITY 1832-1932, at 6 (1933).

121. See generally H. Hale Bellot, University Colifge, London, 1826-1926 (1929).

122. Especially important was the report of George Tichnor of Harvard. See Morison, supra note 34 , at 228-38. 
standard of general education and the mind of the laboring classes nearer to a level with those born under more favorable circumstances."123

Together, the group acknowledged "that the diffusion of knowledge among the people is essential to the purity and stability of a republican form of government." 124 Accordingly, they ordained that there should be a professorship on "The Law of Nations and Constitutional Law" at their new university. They also requested and received from the state supreme court a ruling that waived two years of the apprenticeship requirement for those regularly attending its law lectures. ${ }^{125}$ Benjamin F. Butler was chosen to establish the program. ${ }^{126}$ Butler was not only a Jacksonian Democrat, but also a close adviser and ally of Governor Van Buren, ${ }^{127}$ in whose law office Butler had served his clerkship. ${ }^{128}$ The opening of the law school was postponed for several years while Butler served as Attorney General of the United States during the Jackson administration. Alas, Butler's program survived only one year. In addition to a financial convulsion of the university, resulting in part from the Panic of 1837, the number of students attracted was probably disappointing. ${ }^{129}$ In any case, the Law Department subsided for a time. ${ }^{130}$

A similar and somewhat more enduring effort was pursued upstate at Hamilton College in Clinton, not far from Utica-the center of Finney's religious revivalism. Hamilton had been established as an Indian mission in 1789 by Samuel Kirkland, a traditional Congregationalist minister. ${ }^{131}$ When a Jacksonian member of the state senate died in the cholera epidemic of 1832, he left his estate to endow a law professorship in the College. ${ }^{132}$ In 1835, John Hiram Lathrop was appointed the first Maynard Professor of Law, History, Civil Polity, and Political Economy. ${ }^{133}$ While little is recorded of Lathrop's teaching at Hamilton, we know that he was a Barnburner adhering to Leggett's doctrine of free speech, free schools, free labor, and free trade. He was especially outspoken on the issue of freedom of religion. He believed the ideal professor should

123. Henry Adams, The Life of Albert Gallatin 648 (Peter Smith 1943) (1879) (referring to Gallatin's dream for an egalitarian educational system).

124. JoNEs, supra note 120 , at 12.

125. See General Rules, 9 Wend. 224 (N.Y. 1832) (ruling that "any portion of time not exceeding two years spent in regular attendance upon law lectures in the University of New-York, shall be allowed in lieu of an equal portion of clerkship in the office of a practicing attorney of this court").

126. See generally Winlam D. Driscoll, Benjamin F. Butler: LawYier and Regency PolmtCIAN (1987) (detailing Butler's life of public service as a Civil War general, prominent New York lawyer, and U.S. Attorney General under Presidents Jackson and Van Buren).

127. See James C. Curtis, The Fox at Bay: Martin Van Buren and The Presidency, 18371841 , at 61 (1970). 1870).

128. See L.B. Proctor, The Bench and Bar of New York 753-55 (New York, Diossy \& Co.

129. The program may have attracted as few as fifteen students. See ReED, supra note 3, at 152.

130. See Leslie Jay Tomprins, The New York University Law School: Past and Present 11-14 (1904).

131. See Charles Eldier Allison, A Historical Sketch of Hamlton College 15-20 (Yonkers, 1889).

132. See id. at 40.

133. See Frank F. Stephens, A History of THE UNIVERSTry of Missouri 31 (1962). 
be "too ... Christian to be sectarian,"134 and, although regular in his attendance at divine services, he long refused to join a church. He was also an advocate of women's rights to higher education and vocational opportunity. In 1841, Lathrop moved West to become the founding president of the University of Missouri, ${ }^{135}$ and law at Hamilton became the work of Theodore Dwight. Dwight was another native of upstate New York whose law teaching won much favor. ${ }^{136}$ In 1858, he left Hamilton College for the Columbia Law School. ${ }^{137}$

Among the early converts to Finney's modified Puritanism was John Jay Shipherd, who organized the Oberlin Institute in 1833, stating its purpose to be "the education of gospel ministers and pious school teachers."138 Oberlin was not a college of choice for young patricians. Part of the Oberlin environment was daily, hard, physical work for every student-the sort that the Indiana legislature sought to impose on both teachers and students. No amenities were provided at Oberlin and no entertainments were permitted. The college was not only open to black students, ${ }^{139}$ but, through Finney's churches, it actively recruited them long before any other college recruited students of any color or class. It soon merged with the neighboring female academy, also established by Shipherd, to become the world's first coeducational college. ${ }^{140}$ Oberlin was in antebellum times one of the largest colleges in America. It was a prominent academic manifestation of the Barnburning culture of "equal rights." At least two Oberlin students would eventually number among the first black lawyers, though both also "read law" with other mentors. ${ }^{141}$

Michigan statehood came in 1837, just as Butler, Lathrop, and Edward Wade (a Cleveland lawyer then teaching at Oberlin) were embarking on their law-teaching efforts in New York and Ohio. As early as 1817, the Jeffersonian Chief Judge of the Territory of Michigan argued for the establishment of a law department like that at William and Mary, one that would educate republican leaders for the Territory of Michigan. ${ }^{142}$ Reflecting the same impulse, the state constitution directed the legislature to establish a university that would, among

134. See Jesse H. Coursault, John Hiram Lathrop, in 11 Dictionary of AmERICAN Biography 16, 17 (Dumas Malone ed., 1933).

135. See Stephens, supra note 133, at 32 . At Missouri, Lathrop voiced opinions about public higher education reflecting the ideas of Jefferson and Bentham and the founders of New York University: He favored applied instruction over theoretical, and egalitarian education over elitist. See JoNAs VIIES, The University of Missourr: A CentenNIAL History 29-30 (1939) (discussing Lathrop's address delivered on the dedication of the College Building in 1843).

136. He was born in Catskill in 1822, the grandson of Timothy Dwight, the President of Yale. See History of Columbia LaW School, supra note 44, at 33-43.

137. See id. at 42.

138. See 1 FletCHER, supra note 75 , at 119.

139. See id. at 170-78, 189, 248-50. Other American colleges had earlier received black students without fanfare. For instance, one of the first students enrolled at Lafayette College in Easton, Pennsylvania was black. See Alfred W. Gendebien, The Biography of A College: Benng The History OF THE THIRd Half-Century of Lafayette College 4 (1986). (1962).

140. See Frederick Rudolph, The American College and University: A History 311

141. George B. Vashon, who received his A.B. from Oberlin in 1844, was the first black lawyer in Pittsburgh and practiced for several decades in Syracuse. See 2 FLETCHER, supra note 75, at 533.

142. See Brown, supra note 3, at 3-6. 
other things, teach law to the youth of the new state. ${ }^{143}$ The governing board first sought to employ as its president George Bancroft of Harvard, ${ }^{144}$ one of the few New Englanders who publicly supported the Jacksonian reforms. ${ }^{145}$ Bancroft declined and recommended Henry Philip Tappan, who was subsequently appointed. 146

Tappan was another native of upstate New York and had served on the faculty of New York University. ${ }^{147}$ Tappan's ideas about education were essentially those of Jefferson and Bentham. Under Tappan's leadership, the University of Michigan moved away from the rigidly classical model of Harvard and Yale toward studies with more direct application to the lives being led by nineteenth century graduates.

In 1859, President Tappan opened a law department that would soon become a prominent feature of the university. No tuition was charged; the only admission requirements were that the candidate be eighteen years of age and furnish "evidence of good moral character." 148 Cooley was the youngest of the law school's three faculty members, who were selected by a committee formed by the regents of the university on the advice of the members of the Supreme Court of Michigan. ${ }^{149} \mathrm{He}$ was the only one willing to move to Ann Arbor, and so he assumed administrative responsibility.

The department quickly attracted students from most of the states of the old Northwest Territory, and then from states west of the Mississippi. Two years after the Civil War ended in 1865, the law school enrolled 395 students, making it at the time the largest department or school of law in America. ${ }^{150}$ For the first quarter century of its existence it would bear the flags of both Jacksonian populism and Jeffersonian conceptions of republican leadership.

The differences between the Michigan law department and the law school administered by Langdell were numerous. Cooley was admired for the clarity of his lectures and his courtesy to students; Daniel Coit Gilman, perhaps the most celebrated educator of the age, acclaimed Cooley as the most lucid lecturer he had ever heard. ${ }^{151}$ Langdell, in contrast, was reviled by most of his students for his obstinate refusal to supply them with answers to his many annoying questions. ${ }^{152}$ Cooley taught Constitutional Law, a subject that Langdell did not regard as law at all and that was not taught in Langdell's school in the

143. Mrch. Const. of 1835 , art. X, $\$ 5$.

144. See Thomas M. Cooley, The Founding of the Law Department of the University of Michigan, in Sentor law Class annual 93, 95 (Ann Arbor, 1894).

145. See Schlesinger, supra note 87, at 159-76.

146. See Cooley, supra note 144 , at 95 .

147. See H. W. Schoenberger, Henry Philip Tappan, in 18 Dictionary of American BIOGRAPHY 302 (Dumas Malone ed., 1936).

148. Brown, supra note 3 , at 269-70.

149. See id. at 11-14.

150. See REED, supra note 3, at 195.

151. See Hutchins, supra note 2, at 435.

152. See Franklin G. Fessenden, Rebirth of the Harvard Law School, 33 HARv. L. REv. 493, 498503 (1920). See generally Charles Eliot, Langdell and the Law School, 33 HaRv. L. Rev. 518, 523 (1920) (discussing the theory behind Langdell's pedagogy). 
1870 s. ${ }^{153}$ In all that he taught, Cooley emphasized the historical and cultural origins of law and the social and political aims it is shaped to serve. Langdell, on the other hand, taught his students that American law (like Lord Coke's) is an internally complete discipline, rather like chess, ${ }^{154}$ and is formed and best understood without regard for its social, economic, and political consequences. ${ }^{155}$

Cooley's law school took pride in being open to all literate Americans. Academic failure was unknown. The curriculum extended over only two short academic years; students learned what they thought they needed to know and then moved on, often to careers of public service. Neither Michigan nor Harvard ever denied admission to a student because of his race, and both graduated black lawyers soon after the Civil War. ${ }^{156}$ Michigan was also a leader in educating women in law, and was said in 1890 to have by far the largest number of law alumnae. ${ }^{157}$ By contrast, Langdell's law school aspired to be exclusive. Its curriculum was extended to three years, academic failure was common, and admission standards were gradually elevated. ${ }^{158}$ In these respects, Langdell's students were early examplars of human capitalism; they were making a heavy investment from which they expected a suitable return.

Although Cooley lectured at Johns Hopkins ${ }^{159}$ and Yale, ${ }^{160}$ he taught regularly only at Michigan. In addition to his teaching, Cooley edited for contemporary readers William Blackstone's Commentaries on English Law. ${ }^{161}$ Blackstone had been through many previous American editions, the first and most important having been prepared by St. George Tucker, Wythe's successor at William and Mary. ${ }^{162}$ Even more frequently than the work of James Kent, ${ }^{163}$ Blackstone's Commentaries served as the first law book for most Americans entering the legal profession in the nineteenth century. Indeed, more than a few American lawyers may very well have read little else. ${ }^{164} \mathrm{~A}$

153. See WARREN, supra note 42 , at $409-13$.

154. The metaphor is not original. See, e.g., Brainerd Currie, The Materials of Law Study, $8 \mathrm{~J}$. LEGAI EDUC. 1, 20 (1955).

155. See Eliot, supra note 152 , at 523 .

156. For an account of the experience of the first African-American student at the Harvard Law School, see J. Clay Smith, In Freedom's Birthplace: The Making of George Lewis Ruffin, The First Black Law Graduate of Harvard University, 39 How. L.J. 201 (1995).

157. See Lelia J. Robinson, Women Lawyers in the United States, 2 GreEN BAG 10, 17 (1890).

158. See Robert B. Stevens, Law School: Legal Education in AMERICa from the 1850s to THE 1980s, 36-37 (1983).

159. See JoNES, supra note 2, at 222-26.

160. See Leroy S. Boyd, Cooley Bibliography 4 (1933) (unpublished bibliography, Interstate Commerce Commission).

161. See, e.g., 1-4 Willam Blackstone, Commentaries (Thomas M. Cooley ed., Chicago, Callaghan \& Co., 3d ed. 1884) (1765). (1978).

162. See Joel Seligman, The High Citadel: The Influence of Harvard Law School 22

163. 1-4 James Kent, Commentaries on American Law (New York, O. Halsted 1826).

164. An Indiana lawyer of Cooley's time explained that "Blackstone's Commentaries are considered the great medium of instruction. The young man who has carefully read these, and who has for a short time written for a practicing attorney, is admitted to the bar." Michael H. Harris, The Frontier Lawyer's Library; Southern Indiana, 1800-1850, Test Case, 16 AM. J. LEGAL HIST. 239, 241 (1972) (citation omitted). 
glancing knowledge of that book might, in 1870 , have sufficed to enable personable applicants to secure licenses to practice law in many, perhaps most, states. With his edition, Cooley helped to keep that tradition of an open profession alive, an action that would have endeared him to William Leggett and the Barnburners. In introducing his work, he gave extensive advice to young men and women who proposed to enter the legal profession without academic training in law. ${ }^{165}$ Those novices were an object of contempt for Langdell, and it is unimaginable that he would have encouraged them as Cooley did.

The differences between Cooley and Langdell as law teachers reflected other, personal differences. Langdell, although of rural origins, secured an elaborate education, at Phillips Exeter Academy, Harvard College, and Harvard Law School. ${ }^{166} \mathrm{He}$ remained at the law school an additional year after graduating to assist Professor Parsons in completing his text on the law of contracts and was twenty-seven when at last he commenced law practice in New York in 1854. He saw himself as a member of an elite social class. ${ }^{167}$ Cooley, in contrast, had but three years of school in an academy in Attica, New York, and one year as a clerk in the office of his New York congressman, Theron G. Strong. $168 \mathrm{He}$ saw himself as a member of a classless society. He had little regard for wealth, social status, or intellectual pretension as insignia of moral worth. And while he relished the affection and respect of his students and colleagues, he did not put himself forward as a person entitled to extraordinary regard. 169

Both Cooley and Langdell had as young men suffered from shyness, and neither was successful in attracting a professional clientele. ${ }^{170}$ Langdell practiced for fourteen years in New York as a reclusive lawyer's lawyer. Cooley partially overcame his shyness by throwing himself into a wide range of social and political activities. By 1851, not yet thirty, Cooley was a sometime orator at public celebrations. ${ }^{171} \mathrm{He}$ was also a sometime political journalist, and a leader in the literary society of his village. ${ }^{172} \mathrm{He}$ was an omnivorous reader. Langdell, debilitated by poor sight, apparently read only law, and mostly English law at that. He seems to have had little or no experience as a public speaker before coming to Harvard.

Unsurprisingly, their politics were opposed. It was said that Langdell longed for the time of the Plantagenet royalty ${ }^{173}$ and had no interest in "any

165. See 1 Blackstone, supra note 161, at 1-37. Cooley was not the only late nineteenth century law teacher to edit Blackstone. Another edition was prepared by William Gardiner Hammond, the founder of two law schools, at the University of Iowa and at Washington University. 1-4 WIILIAM Blackstone, Commentaries (William G. Hammond ed., San Francisco, Bancroft-Whitney Co. 1890) (1765).

166. See SutherLand, supra note 37 , at 165.

167. See id. at $165-66$. (1914).

168. Strong's autobiography is Theron G. Strong, Landmarks of a LawYer's Lifettme

169. See JoNes, supra note 2 , at $255-57$.

170. See Seligman, supra note 162, at 31-32.

171. See JoNes, supra note 2, at 34-39.

172. See id.

173. See Seligman, supra note 162 , at 30 . 
development of the law" occurring after $1850 .{ }^{174} \mathrm{He}$ seems to have been among the few who took no more than moderate interest in the progress of the Civil War that raged around him. And despite his rural origins, he had little interest in the affairs of farmers, and perhaps even less in those of industrial workers and their families, two groups comprising the bulk of his fellow citizens. When asked in 1871 to join the reformist American Social Science Association, he declined, explaining that he had too little interest in changing the law to assume the obligations of membership. ${ }^{175}$ However, he did participate in the work of that organization when it became interested in raising the standards of the professions so as to exclude the ignorant and the unwashed. In seeking a label for the politics of Langdell, one is attracted to the term Federalist, the label worn by the openly elitist and oligarchical party of Alexander Hamilton. ${ }^{176}$

Cooley left the Democratic party of his family and friends in the 1850 s to join the Free Soil movement, and eventually followed Lincoln into the Republican party. Like Lincoln, whom he came to revere, he was committed both to emancipation and the preservation of the Union. He identified the interests of farmers and other working poor as the central concern and responsibility of democratic government, but along with Leggett he supposed that those interests would generally be favored by governmental passivity, fearing that government involvement usually resulted in preferential treatment of the rich and powerful. ${ }^{177}$

Cooley was appointed by the Republican legislature in 1857 to compile the state's statutes. He excelled at the task, and on the basis of that work and his careful advocacy in cases argued to the court, he was appointed reporter of the decisions of the Supreme Court of Michigan in 1858. This was the position he held a year later when he was appointed by President Tappan to the university faculty and made responsible for the development of a program of legal education to serve the people.

Langdell was picked for his position by Charles Eliot, the president of Harvard. Eliot was one of the persons most perceptive about the emerging role of higher education in an industrialized America, and it was his vision that Langdell's program sought to implement. In 1875, Eliot explained Langdell's mission:

An institution which has any legal prestige and power, will make a money profit by raising its standard, and that either at once or in a very short time. Its demand for greater attainments on the part of its students will be quickly responded to, and this improved class of students will be [sic] in a marvelously short time so increase the reputation and influence of the institution as to make its privileges and its rewards more valued and more valuable. ${ }^{178}$

174. Samuel Williston, Life and LaW: An Autobiography 200 (1940).

175. See William P. Lapiana, Logic and Experience: The Origin of Modern american LEGAL Education 77 (1994).

176. See Stanley Elkins \& Eric McKittrick, The Age of Federalism: The Early American RePUBLIC, 1788-1801, at 103 (1993).

177. See JONEs, supra note 2 , at $16-68$ for an account of Cooley's early politics.

178. 2 WARREN, supra note 42, at 397 (quoting President's Annual Report for 1874-75). 
Responding to Eliot's leadership, Langdell invented the casebook, grilled his students on their reading of cases, set written examinations, extended the length of his program to three academic years, and raised admission standards to require a baccalaureate degree. All of these reforms were designed to elevate the professional status of Harvard Law graduates, and they had precisely that effect.

Associated with Langdell's reforms was an intellectual framework (it can hardly be called a philosophy of law) resting on astonishingly elitist assumptions. Among these were the notions that American law is an empirical science accessible only by means of prolonged study; that the common law is the same in all states and that it can be discerned by a careful reading of selected English, Massachusetts, and New York decisions and making the correct inductions from those cases; that what intellectually challenged legislators and judges say or think is not law; and that the Constitution of the United States and the constitutions of the states are not law, but mere politics. ${ }^{179}$ Langdell's fullest statement of his theory was presented to Cooley's audience in the Hemenway Gymnasium in 1886. Most memorable among his remarks that day was his statement that "printed books are the ultimate sources of all legal knowledge."180 Accordingly, he asserted, "What qualifies a person, therefore, to teach law is not experience in the work of a lawyer's office, not experience in dealing with men, not experience in the trial or argument of causes-not experience, in short, in using law, but experience in learning law."181

These notions had two notable features: They conformed comfortably to the secularized Puritanism of the Beacon Hill intellectual community, and they rationalized the academic credentialization of the American legal profession. They were never accepted by many, even at Harvard. ${ }^{182}$ Langdell's colleague, John Chipman Gray, privately noted to Eliot that Langdell's "intellectual arrogance and contempt is astonishing" and opined that "a school where the majority of the professors shuns and despises the contact with actual fact ... will and ought to go to the devil."183 Holmes, who for a brief time was also Langdell's academic colleague, was in private equally contemptuous of Langdell's thinking. He ridiculed the claim that the law is empirical science, and compared Langdell's teaching to that of a biology teacher who "would give one of his pupils a sea urchin and tell him to find all about it he could."184 He condemned Langdell's casebook on contracts as a "misspent piece of marvellous ingenuity" that served the "powers of darkness,"185 and he dismissed Langdell as a "legal

179. This last is an idea often associated with John Austin, see John ChIPMAN Gray, THE NATURE AND SOURCES OF LAW (1909), but it is not confirmed that Langdell ever read Austin.

180. HaRVARD, A Record of Commemoratton, supta note 1 , at 86.

181. Id.

182. See Paul D. Carrington, Hail! Langdell!, 20 L. \& Soc. INQuIRY 691, 716-39 (1995).

183. Letter of January 8,1883, quoted in Howe, supra note 56, at 158.

184. LIVA BAKER, THE JUSTICE FROM BEACON HILI 208-09 (1991).

185. Id. at 208. Holmes's published reviews of Langdell were less harsh. See Book Notice, 14 AM. L. Rev. 233-35 (1880); Book Notice, 6 AM. L. Rev. 53-54 (1872). The latter, a review of the second edition, was unsigned. For attribution of authorship, see Saul Touster, Holmes a Hundred Years Ago: The Common Law and Legal Theory, 10 Horstra L. Rev. 673, 695 n.91 (1982). 
theologian."186 Nevertheless, on that commemorative occasion in 1886, Holmes managed some very kind words about the case method, if not about the theory offered by Langdell to justify it. ${ }^{187}$

Despite the frailty of its intellectual premises, Langdell's program became a huge success in its second decade. Eliot's prophecy was fulfilled. By 1886, the University of Michigan had begun to see the light, lengthening its program, raising admission standards, and adopting the case method. Cooley did not oppose these changes; indeed, he fostered the extension of the academic calendar at Michigan. ${ }^{188}$ Nevertheless, he found them an occasion for terminating his own teaching, for they were dissonant with his own aims as a teacher. And it was likely his discomfort with what Eliot and Langdell were doing that prompted his remark at the rostrum of honor on law as the common thoughts of men-a remark that was surely intended to impose some discomfort on his hosts.

\section{COOLEY AND Holmes}

Holmes was perhaps the first American to gain status in the legal profession as an intellectual and a theorist. In his talk at Northwestern University in 1902, he conceded that there was some truth in Cooley's observation that the law is and ought to be rooted in commonplace morality. Cooley would have agreed with much that Holmes said on that occasion, especially that law is not unchanging, but an "eternal pursuit."189 But when Holmes went on to characterize law as "a field for the lightning of genius," or to say that from law "may fly sparks that shall set free in some genius his explosive message," 190 Cooley might have risen from his seat to protest.

Cooley denied that a great mind can, by its own exertions, create new principles of morality or law. He also insisted that "no one can think the thoughts of law with its reason, unless he is in sympathy with the morality and truth which underlies it."191 In response to Holmes he might have quoted Cicero, as he did on other occasions, to the effect that "the fruits of speculative genius in government are of little value." 192 Cooley sided with Thucydides, who was perhaps the first to record the opinion that:

On the whole it is the more ordinary men, in contrast to the more intelligent, who run cities better. The intelligentsia want to appear wiser than the laws, and to outdo whoever is currently speaking in public, supposing that there is no better way of showing their good judgment; and by this kind of behavior they usually bring disaster on their cities. But those who distrust their own intelligence acknowledge that they are more ignorant than the laws and less able than an accomplished speaker to find fault with what is said: being impartial judges

186. Book Notice, 14 AM. L. Rev. 234 (1880).

187. See Harvard, A Record of Commemoration, supra note 1 , at 276-77.

188. See Brown, supra note 3 , at 102-03.

189. Holmes, supra note 31 , at 276-77.

190. Id.

191. JoNes, supra note 2 , at 228 (citations omitted).

192. Sources of Inspiration in Legal Pursuits, 9 W. JURIST 515, 520-21 (1875) (address of Hon.

Thomas M. Cooley to the Iowa State Bar Assoc., Des Moines, May 1875). 
rather than competitors, they are for the most part successful. We must follow that model, and must not be excited by cleverness and intellectual rivalry into giving advice to you, the citizen body, contrary to our true beliefs. ${ }^{193}$

Thucydides could have been assured that Holmes was himself far from rash in his judicial behavior. He was not one to ruin a country by dramatic exhibitions of his wit in crafting novel solutions to public problems. But he did possess some of the characteristics of judges whom Thucydides urged us not to imitate: He was in some ways given to "intellectual rivalry," he seldom mistrusted his own cleverness, and he desired to appear "wiser than the laws." While Holmes has sometimes been regarded as a prophet of pragmatism, ${ }^{194}$ he was in truth little concerned with practical politics. Perhaps he could be better described as a theoretician of pragmatism. When accepting his appointment to the Harvard Law faculty, he requested that his title be "professor of jurisprudence," to signify his aim to be a theoretician. ${ }^{195}$ When he resigned his faculty position at the Harvard Law School, he gave the reason that " the field for generalization inside the body of the law was small, that the day would soon come when I felt that the only remaining problems were of detail and that as a philosopher [1] must go over into other fields ....." "196 As full an expression as any of the spirit of academic elitism was Holmes' assertion that there may be no

more exalted form of life than that of a great abstract thinker, wrapt in the successful study of problems to which he devotes himself, for an end which is neither unselfish nor selfish in the common sense of these words, but is simply to feed the deepest hunger and to use the greatest gifts of his soul. ${ }^{197}$

It may well have been legal theory that he had in mind when he proclaimed the field to be one for the "lightning of genius." The practicing lawyer of the future, he proclaimed, would be the "man of statistics and the master of economics," 198 and he perhaps envisioned that lawyers employing those theoretical disciplines might unleash the lightning of their genius and provide us with explosive messages.

An important source of the difference between Cooley and Holmes lay in the methods by which they were selected as judges. Massachusetts is among the very few states that has never provided for the popular election of judges. It is difficult to imagine Holmes as a candidate for public office. To secure election, he would have needed a more endearing public persona, an adaptation that

193. 3 Thucydides, The History of the Pelopennesian War, pt. 38, at 77 (P.J. Rhodes trans., 1994) (speech of Cleon, son of Cleaentus). Cooley elaborated on this theme in Lecture I: The Sentiment of Equality in American Politics, Johns Hopkins University (1878) (unpublished manuscript in Box 1, Cooley Collection, Bentley Library, University of Michigan) [hereinafter Lecture I]. Cf. Abraham Lincoln, The Perpetuation of Our Political Institutions, Address to the Young Men's Lyceum of Springfield, in 1 Collected Works of Abraham Lincoln 108, 111-12 (Roy P. Basler ed., 1953) (admonishing his audience to guard against mob rule).

194. See Thomas C. Grey, Holmes and Legal Pragmatism, 41 Stan. L. Rev. 787, 788 (1989).

195. See Howe, supra note 56 , at 260-61.

196. BAKER, supra note 184 , at 270.

197. Oliver Wendell Holmes, Law in Science and Science in Law, 12 HARV. L. REV. 443 (1899).

198. See Oliver Wendell Holmes, The Path of the Law, 10 Harv. L. Rev. 457, 474 (1897). 
would likely have lowered his appreciation of the office and its role in the constitutional scheme. As a judge holding life tenure, Holmes was seldom required to consider the "common thoughts of men."

Today the conventional wisdom is that electing judges is a bad idea, ${ }^{199}$ and assuredly the practice does seem to put a court's independence of judgment at risk. Nevertheless, the empirical evidence lends no more than weak support to the conventional wisdom. ${ }^{200}$ Cooley defended the practice, ${ }^{201}$ and demonstrated that elected judges need not be moral cowards. While he was mindful of what his constituents thought about matters coming before his court, he sometimes made decisions that he knew would be resented by many, perhaps most. Widely unpopular decisions were in his view warranted and even required when public opinion was uninformed, or formed in haste or passion. ${ }^{202}$ For Cooley, the writing of appellate opinions was an opportunity to educate his constituents and to justify decisions by reference to controlling texts within the framework of widely shared moral premises. He accepted the risk that his effort might fail and that he might be thrown out of office on account of that failure. He also disavowed pandering and despised it in judicial colleagues. ${ }^{203}$

Was either Holmes or Cooley a "great judge"? Roscoe Pound placed both on his celebrated list of ten. ${ }^{204}$ Holmes was not a modest person, ${ }^{205}$ and likely thought of himself in such terms. He was himself among the first to employ the concept of a great judge when in The Common Law he praised Lemuel Shaw with that term. ${ }^{206}$ Richard Posner, himself likely as good a professional judge as any of our time, has confirmed Holmes' self-estimate. ${ }^{207}$ Judge Posner's assessment is based in large measure on Holmes' literary talent, and the result-

199. See, e.g., Steven P. Croley, The Majoritarian Difficulty: Elective Judiciaries and the Rule of Law, 62 U. CrI. L. Rev. 689 (1995) (suggesting that judges in elective states may jeopardize a commitment to upholding constitutionalism and rules of law in answering majoritarian political pressures).

200. See generally Daniel R. Pinello, The Impact of Judicial-Selection Method on StateSUPREME-COURT POLICY: INNOVATION, REACTION, AND ATROPHY (1995) (conducting an empirical study illustrating that the judicial selection method often offers no reliable guidepost to judicial action).

201. See Everett S. Brown, The Contribution of Thomas M. Cooley to Bryce's "American Commonwealth," 31 MrCH. L. REv. 353 (1933) (noting Cooley's defense of the elected judiciary as he presented it to Bryce).

202. Compare the dictum of Hamilton writing as Publius:

The republican principle demands, that the deliberate sense of the community should govern the conduct of those to whom they intrust the management of their affairs; but it does not require an unqualified complaisance to every sudden breeze of passion, or to every transient impulse which the people may receive from the arts of men, who flatter their prejudices or betray their interests.

THE Federalist No. 71, at 369-70 (Alexander Hamilton) (George W. Carey \& James McClellan eds., 1990).

203. See Wise, supra note 5, at 1555 (describing Cooley's disgust with Thomas R. Sherwood, a fellow Michigan Supreme Court Justice, who solicited delegates for his nomination to the court and asked Cooley to remand a case in which Sherwood had been counsel).

204. See Roscoe Pound, The Formative Era of american Law 30 n.2 (1938).

205. See Yosal Rogat, The Judge as Spectator, 31 U. CHr. L. Rev. 213, 253 (1964) (arguing that Holmes' skepticism in no way undermined his self-confidence). For a contrary inference based largely on Holmes' judicial conduct, see Wallace Mendelson, Mr. Justice Holmes-Humility, Skepticism and Democracy, 36 MinN. L. Rev. 343, 346-47 (1952).

206. See Holmes, supra note 32 , at 106.

207. See, e.g., Richard A. Posner, Cardozo: A Study of Reputation 138-40 (1990). 
ing frequency with which he is cited. By this measure, Judge Posner has also proclaimed the greatness of Cardozo ${ }^{208}$ and Hand. ${ }^{209}$

Cooley's judicial opinions do not measure up by Judge Posner's criterion. Although Cooley did outgrow his shyness, he remained a genuinely modest man. He did not appear to strive to be a "great judge," and might well have denied the existence of such a class. While there were many judges he admired, he seems never to have applied the term "great" to any. One of his own strengths as a judge was that attributed by Holmes to Shaw: He possessed an "accurate appreciation of the requirements of the community whose officer he was." 210 Because he viewed the moral premises of democratic law to be derived from the commonplace morality of self-governing citizens, Cooley simply did not view the act of making a judicial decision or a legal argument as an opportunity for creative genius. In contrast, Holmes was "alienated from his people and from his culture. ... [and] playing a role, serving the Republic that in many ways he had come to disdain."211

While Cooley's judicial opinions were widely admired for their clarity, they were not literary triumphs. Although a consumer of English literature and an occasional poet of modest talent, he did not encumber his professional writing with metaphors or literary allusions. He wrote not to inspire his readers with an appreciation of the cosmos, nor to attract the notice of fellow judges, but to be understood by Michigan lawyers and any other citizens who might take an interest in his decisions. There is a dictum said to have been repeated by judges serving on the same court with Learned and Augustus Hand: "Read Learned, but follow Gus."'212 Cooley was a judge more in the mold of Gus Hand.

Not all contemporary observers identifying greatness in judging would share Judge Posner's emphasis on quotability or frequency of citation. Today many would likely stress a judge's influence on the shaping of "impact" decisions-a great judge being one who causes a decision of great social consequence. $^{213}$ By that measure, neither Holmes nor Cooley could be appraised as great. Indeed, that form of greatness would have been eschewed by both. Cooley regarded it as his professional duty to reflect and express the moral precepts and expectations of the people of Michigan, not to change them to his own taste or even to that of his fellow lawyers. An adjective he used to describe judges whom he admired was "safe," 214 that is, a judge unlikely to stray from the

208. See id. at 142. For a different assessment, see John T. Noonan, JR., Persons and MASKS OF THE LAW (1976). Noonan refers to Cardozo as "the most justly celebrated of American common-law judges." Id. at 111. He supports that assessment by close analysis of a very few decisions, not by counting citations. Noonan also offers some criticism of Cardozo's impersonal, rule-oriented approach. See id. at $138-39,142-43,150-51$.

209. See Richard A. Posner, The Learned Hand Biography and the Question of Judicial Greatness, 104 Yale L.J. 511, 522-23 (1994) (reviewing Gerald Gunther, Learned HaND: The MaN and THE JUDGE (1994)).

210. HoLMES, supra note 32 , at 106.

211. Transcript, Objectivity and Hagiography in Judicial Biography, 70 N.Y.U. L. REv. 569, 570 (1995) (comments of Prof. Robert Gordon).

212. Id. at 563 (comments of Judge James L. Oakes).

213. See, e.g., Laura Kalman, The Strange Career of Legal Liberalism (1996).

214. Wise, supra note 5, at 1552 (citing a Cooley journal entry describing Judge Marston). 
commonplace, and certainly not inclined to make an "impact" decision. In this, Cooley preceded Herbert Croly, the intellectual leader of the Progressive Movement, which undertook radical transformation of American law in the first fifteen years of the twentieth century. Croly, in the midst of his call for radical reform, observed that:

The Supreme Court has been, on the whole, one of the great successes of the American political system, because the lawyers, whom it represented, were themselves representative of the ideas and interests of the bulk of their fellowcountrymen; and if for any reason they become less representative, a dangerous division would be created between the body of American public opinion and its official and final legal expositors. If the lawyers have any reason to misinterpret a serious political problem, the difficulty of dealing therewith is much increased, because in addition to the ordinary risks of political therapeutics there will be added that of a false diagnosis by the family doctor. The adequacy of the lawyers' training, the disinterestedness of their political motives, the fairness of their mental outlook, and the closeness of their contact with the national public opinion-all become matters of grave public concern. ${ }^{215}$

Even deep political and philosophical differences between judges will not necessarily result in major differences in judicial conduct. Most cases implicate partisan politics and philosophy only marginally, if at all. Therefore, if Holmes and Cooley had sat on the same bench, they may not have had much taste for one another's company, 216 but they might well have voted together in a high percentage of their cases.

Still, the contemporary assumption is that there was a substantial difference between Cooley and Holmes with respect to their perceptions of the role of the judiciary in a democratic government. Paradoxically, Holmes, the Brahmin, earned a reputation for being deferential to the will of democratic legislatures, while Cooley, the Jacksonian, has been identified with the intrusive arrogance of the Supreme Court in the Lochner ${ }^{217}$ era. These conventional perceptions are much exaggerated. In fact, it may be that the style and elitism of Holmes, reinforced by the pretensions of the profession associated with Langdell's reforms, encouraged the advent of judicial self-aggrandizement that characterizes law in the late twentieth century. One viewing the scene today can see evidence that Holmes' sparks of lightning have freed more than a few robed geniuses willing to impose their explosive messages upon the electorate. While Holmes is entitled neither to credit nor blame for the merit or demerit of such messages, he was in a sense their herald. And Cooley, for good or ill, personified a profession that was too constrained by its fidelity to the "common thoughts of men" and too "safe" to produce judges as aggressive as many who have served on our courts in recent times.

215. Herbert Croly, The Promise of American Life 134 (1909).

216. Apparently for reasons of class difference, Cooley did not enjoy the company of James Valentine Campbell, who was his colleague on the court for 20 years and his colleague on the law faculty for 25 years. Cf. Wise, supra note 5, at 1549-50 (recounting a difference of opinion between Cooley and Campbell in the State Law Tax Cases).

217. Lochner v. New York, 198 U.S. 45 (1905) (striking down a state law regulating the hours worked by bakers on equal protection grounds). 
If Holmes' career had the effect of encouraging judicial hubris, the effect might be traced back to The Common Law, his 1881 lectures emphasizing the creative role and the responsibility of judges working in the English tradition. There was little in this work that was genuinely new; Cooley's treatment of the subject in his treatise on torts, published in 1879, acknowledged the same role of judges, albeit in language less elevated than that employed by Holmes.218 As Martin Golding has observed, the celebrated opening passage in The Common Law about logic and experience is best understood as an attack on Langdell, the champion of logical law. ${ }^{219}$

Holmes was writing about the evolution of private law, and does not appear to have envisioned public "impact decisions" as we have come to know them. As Mark Tushnet has noted, Holmes offered no guidance, either theoretical or practical, as to how a good judge might choose among policies competing for his or her approval. ${ }^{220}$ Indeed, Holmes later wrote that he had no criterion for "the goodness or badness of laws ... except what the crowd wants."221 Yet, more than a few twentieth century judges have, like Holmes, come to assume that American law has a large political dimension. They share his view that there are hence no criteria for judgment, and conclude that they may indulge their own political fancies, however idiosyncratic.

Perhaps the most distinctive feature of The Common Law is its style. It was written for a very small and well-informed audience, and was filled with Delphic expressions that such an audience might find more evocative than informative. This may also be true of Holmes' opinions, especially those authored in dissent. It is possibly as much for this reason as any other that he has been revered by the intellectual elite, for his lofty style marked him indelibly as a legal academic, perhaps in some sense the first American legal academic.

Cooley's Constitutional Limitations was a very different kind of work, addressed to an audience extending beyond the legal academy. ${ }^{222}$ It synthesized much state constitutional law protecting citizens from the arbitrary exercise of power. The corpus of case law that Cooley synthesized reflected his own Jacksonian mistrust of legislatures as bodies willingly manipulated by the rich and powerful to the detriment of the working poor. But he also noted that state constitutional law called for judicial self-restraint, a virtue refiecting an equally strong mistrust of professional judges and their propensity to impose the values of their class and advance their interests. ${ }^{223}$ "A public office is a public trust," 224 he later affirmed (in an exceptionally economic expression), and that

218. See COOLEY, supra note 15 , at 11-20.

219. See Martin P. Golding, Holmes's Jurisprudence: Aspects of Its Development and Continuity, 5 SOC. THEORY \& PRAC. 183, 201 (1979).

220. Mark Tushnet, The Logic of Experience: Oliver Wendell Holmes on the Supreme Judicial Court, 63 VA. L. REv. 975, 1049 (1977).

221. I Holmes-Poliock LetTers 163 (Mark DeWolfe Howe ed., 2d ed. 1961).

222. Cooley told a colleague that he had written the book as an "attorney's companion," a laborsaving device for students, and a manual for "minor officials." JoNEs, supra note 2, at 140 n.49.

223. See COOLEY, supra note 9, at 38-84. Development of this point is beyond the scope of this article.

224. T. M. Cooley, Liability of Public Officers to Private Actions for Neglect of Official Duty, 3 S.L. REv, 531, 531 (1877). 
trust relationship included judicial office. Judges, he believed, are called upon to sacrifice their personal political interests to the culturally derived meanings expressed in the legal texts they undertake to obey and enforce. ${ }^{225}$

Cooley paused only infrequently in his writing to fault judges, but he did criticize the Court that decided Dartmouth College v. Woodward ${ }^{226}$ for making an unwarranted extension of the Contract Clause ${ }^{227}$ in the federal Constitution. ${ }^{228}$ Dartmouth College was an early "impact decision" disabling states from revoking corporate charters; its impact was to confer a benefit on the wealthy and the powerful by weakening the ability of legislatures to protect the public from private mendacity.

James Bradley Thayer drew in part on the Cooley treatise in his famed 1893 lecture, which cautioned the Court against intrusive interference with democratic legislation. ${ }^{229}$ So did Louis Brandeis in an unpublished lecture delivered in 1892 before the Joint Committee on Liquor Law of the Massachusetts Legislature. ${ }^{230}$ And, in 1936, in one of his most important opinions upholding the legislative responsibility of Congress, Justice Brandeis relied substantially on the authority of Cooley's treatise. ${ }^{231}$ Thayer may have carried Cooley's caution to another level when he likened the role of the court in reviewing the work of a legislature to its role in reviewing the verdict of a jury, and when he called on the court to sustain and enforce any legislation that could be supported by reason. ${ }^{232}$ Holmes seems generally to have adhered to Thayer's dictum, most notably in his famous dissent in Lochner. ${ }^{233}$ Learned Hand, Thayer's student, carried Thayer's teaching still further, to the point of favoring repeal of the Due Process Clause as an open invitation to judges to intrude on

225. Cf. Piero Calamandrei, Procedure and Democracy 37 (John Clarke Adams \& Helen Adams trans., 1956) ("The heroism of the judge can be measured by his degree of success in escaping from the prison of his private life ....").

226. 17 U.S. 518 (1819).

227. U.S. Const. art. I, § 10, cl. 1 .

228. See COOLEY, supra note 9, at 280 (questioning whether a state legislature can legally "bind up its own hands" in a way that prevents it from exercising its sovereign pover); see also Cooley, State Regulation of Corporate Profits, 137 N. AMER. REv. 205, 207-08 (1883) (also arguing that state legislatures lack authority to grant corporations irrepealable franchises or privileges). For an elaborate analysis of the relation of the Cooley treatise to the development of the Contract Clause, see James L. Kainen, Nineteenth Century Interpretations of the Federal Contract Clause: The Transformation from Vested to Substantive Rights Against the State, 31 Buff. L. Rev. 381 (1982).

229. See James B. Thayer, The Origin and Scope of the American Doctrine of Constitutional Law, 7 HaRv. L. REv. 129, 142, 144 (1893) (citing Cooley as authority for the view that the judiciary should be cautious in exercising its constitutional powers).

230. See Stephen W. Baskervilie, Of Laws and Limttations: An Intellectual Portrait of LouIs DEMBITZ BRANDEIS 106-07 (1994).

231. See Ashwander v. Tennessee Valley Auth., 297 U.S. 288, 345 (1936) (Brandeis, J., concurring).

232. See Thayer, supra note 229 , at 147 . On the relation between Thayer's article and Cooley's text, see JONES, supra note 2, at 150 n.74 (remarking on Cooley's profound influence on Thayer regarding the idea of judicial self-restraint).

233. Lochner v. New York, 198 U.S. 45, 75 (1905) (Holmes J., dissenting). See generally Cass R. Sunstein, Lochner's Legacy, 87 CoLum. L. REv. 873 (1987) (suggesting that Lochner represents an aggressively neutral judicial role, dedicated to preserving the existing distribution of wealth). 
political judgments and establish themselves as the third chamber in a tricameral legislature. ${ }^{234}$

Holmes and Cooley came to their similar positions on judicial self-restraint from very different premises. Holmes' professional restraint as a judge was fortified by his indifference, in his maturity, to political issues. Seemingly embittered by his military experience, he was more dour even than most eighteenth century Puritans in his distrust of humanity and its capacity for selfimprovement. He later complained of the many hopeful authors who "make me wonder whether I live on a lower plane than is attainable by man, or whether, as of course I maintain, they are churning the void in the hope of making cheese." 235 " $[1 \mathrm{n}$ the last resort," Holmes concluded, "a man rightly prefers his own interest to that of his neighbors. And this is as true in legislation as in any other form of corporate action." 236

Cooley, in contrast, cared a great deal about many public issues. He, too, was generally pessimistic about the possible benefits of legislated solutions, and he came to ratify Gibbon's doleful dictum "that the united reigns of the Antonines were possibly the only period in history in which the happiness of a great people was the sole object of government."237 But he was not overcome by despair. He continued to see law at its best as "an educating force" that, prudently conceived and administered, could help the citizenry elevate their behavior better to reflect their own republican values of social equality, political self-restraint, tolerance, and mutual respect. 238

Cooley believed, as Holmes did not, that there is a common good measured by common values. For him, the common good centered on the interests of farmers and laborers and their spouses who do the world's work and raise the next generation of good citizens. Cooley prefigured the view more recently expressed by Bruce Ackerman that most people have a "rough-and-ready grasp of the animating constitutional ideals of American democracy,"239 and he sought to embrace those ideals as guides to his conduct as a judge. Like all good Jacksonians, he fully appreciated the core of truth in public choice theory-that legislatures and courts are easily deflected from pursuing the common good by their own self-interests ${ }^{240}$ _but he maintained a base of optimism (disturbingly absent in public choice theory) that professionals committed to serving the common good can enjoy some success. He would not have disagreed with the communitarian aims of contemporary civic republicans such as

234. See Gerald Gunther, Learned Hand: The Man and the Judge 374-75 (1994).

235. Letter to Alice Stopford Green (Aug. 20, 1909), in THE Essential Holmes, 115, 116 (Richard A. Posner ed., 1991). (1873).

236. Summary of Events-Great Britain-The Gas Stokers' Strike, 7 AM. L. REV. 582, 583

237. Thomas M. Cooley, The Influence of Habits of Thought Upon Our Institutions, Second Annual Address Delivered Before the South Carolina Bar Association, in South CARolina Bar Assoc., Proceedings 1 (1886).

238. See Thomas M. Cooley, Law as an Educating Force, Address Delivered at the Annual Commencement of the Law and Dental Schools of the University of Michigan (March 26, 1884).

239. I Bruce Ackerman, We the People: Foundations 4 (1991)

240. See generally Dantel A. Farber \& Phimip P. Frickey, Law and Public Chotce: A CritrCAL INTRODUCTION (1991). 
Frank Michelman, ${ }^{241}$ although he might well have lost patience with the sometimes heated efforts of theorists such as Ackerman and Michelman to distinguish themselves from one another. ${ }^{242}$

Cooley would surely have endorsed with enthusiasm Marc Galanter's recent assertion, perhaps the central insight of those committed to an empirical approach to law, that "what appears [in law] to be top down is really bottom up, that it is the unconscious, the folkways, the proletariat that are the dwelling place of the forces that move (or should move) and shape the social world."243 Like Marc Galanter, Cooley saw "the less formal, the less organized, the less respectable ... not as mere material to be ruled, shaped, tamed, but as another, perhaps principal, source of value and meaning."244

Cooley would have scoffed at contemporary critical theory that denied legal texts can be determinate, but would readily have conceded that meanings are often elusive. ${ }^{245} \mathrm{He}$ perceived in the frequent indeterminacy of texts no justification for self-aggrandizement, but rather a heightened moral duty of judges to be "safe," in other words, responsive to the expectations of the people. ${ }^{246} \mathrm{He}$ does not appear to have reflected deeply on the question: How does the judge know what "the people" think?247 Of course, he relied largely on his own instincts, but he was generally correct in his belief that his sternly Protestant, Jacksonian, and egalitarian values were those of most of his constituents and that these beliefs were acknowledged as prevailing values even by those who did not fully share them. He was "of the people" to a degree that Holmes was not and could not have been had he tried.248

Given these differences between Cooley and Holmes, there is some irony in the contrast between the conventional contemporary estimates of these two judges. Cooley, the man of the people, has been labeled as reactionary, an estimate based largely on the uses to which his scholarship was put by other judges making decisions years after Cooley's death and decades after Cooley had ceased writing legal scholarship. ${ }^{249}$ Holmes, on the other hand, the Boston

241. See, e.g., Frank Michelman, Law's Republic, 97 YALE L.J. 1493 (1988) (contending that only through a modern reconsideration of republican constitutional thought can we make sense of government "by the people").

242. See id. at 1519-24 (attacking Ackerman's populism).

243. Marc Galanter, The Portable Soc 2; or, What to Do Until the Doctrine Comes, in General Education In the Soctal Sciences: Centennial Reflections on the College of the Universtty OF CHICAGo 246, 259 (John J. MacAloon ed., 1992).

244. Id.

245. See, e.g., COOLEY, supra note 9 , at 65.

246. See id. at 65-71.

247. The question asked, for example, in Alasdair C. McIntyre, Whose Justice? Which RaTIONALITY? (1988).

248. Cf. David Millon, Objectivity and Democracy, 67 N.Y.U. L. Rev. 1, 4 n.9 (1992) (discussing Holmes's dissent in Lochner and arguing that for Holmes, the common values of the populace were irrelevant to a judge's decisions).

249. See Kermit L. Hall, The Magic Mirror: Law in American History 222-23 (1989) (labeling "reactionary" Cooley's view that legislatures should avoid regulation of property interests); see also Edward S. Corwin, Liberty Against Government: The Rise, Flowering AND DeciIne of A Famous Judicial CONCEPT 67-68 (1948) (criticizing the influence of Cooley's due process theory on the Supreme Court); StDney Fine, Laissez Fare and the General-Welfare State: A Study of CONFict In AMerican Thought, 1865-1901, 128-129 (1956) (criticizing courts for citing Cooley's 
Brahmin, has been lionized in this century as a "heroic liberal judge[ ],"250 a

concept of laissez faire); Charles G. Haines, The Revival of Natural Law Concepts 117 (1930) (discussing the impact of Cooley's due process theory on courts seeking to limit legislative power); HAROLD M. HyMAN, A MORE PERFECT UNION 352-55, 516-19 (1973) (analyzing the contradictions in Cooley's view of federal powers); Clyde E. JACOBS, LAw Writers and the Courts: The INFluence of Thomas M. Cooley, Christopher G. Tiedeman, and John F. Dilion upon American Constitutional Law 23-63 (1954); PhIl lip S. Paludan, A Covenant with Death 250 (1975) (describing how Cooley's treatise became an instrument of courts and lawyers to transform the Fourteenth Amendment into "corporate property"); ArnolD M. Paul, Conservative CRisis and the Rule of Law: ATtiTUDES OF BAR AND BENCH, 1887-1895, at 142-46 (1960) (describing Cooley's legal conservatism as being peremptory at times); Anwar H. Syed, The Poltrical Theory of American Local GovernMENT 65 n.* (1966) ("Armed with Cooley's Constitutional Limitations, lawyers and judges . . . wrote the doctrine of laissez-faire into constitutional law."); LAURENCE H. TRIBE, AmERICAN Constitutional LAw 571 n.4 (2d ed. 1988) (referring to Cooley's theories as a primary influence on Lochner-era jurisprudence); Benjamin R. Twiss, Lawyers and the Constitution: How Laissez Faire CaMe to The SUPREMIE COURT 34 (1962) (explaining that while Cooley "expressed the dominant ideas of that time," his ideas or "his own application of principles differed from that given them later by the lawyers and judges"); Gary C. Leedes, Justice George Sutherland and the Status Quo: A Biographical and Review Essay, 1995 J. Sur. Cr. Hist. 137, 142 (discussing Cooley's influence on Sutherland); Max Lerner, The Supreme Court and American Capitalism, 42 YALE L.J. 668, 692 (1933) (connecting the publication of Cooley's treatise with "an epidemic fear" among his peers of governmental abridgement of property interests); Stephen A. Siegel, Historicism in Late Nineteenth Century Constitutional Thought, 1990 Wis. L. REv. 1431, $1516 \mathrm{n} .503$ (noting that Cooley's treatise on constitutional law is regarded as one of the two texts most responsible for the rise of laissez-faire constitutionalism). Of these scholars, Twiss is perhaps most extreme, describing Cooley's treatise as a "direct counter" to Karl Marx's Das Kapital. Twiss, supra, at 18. Jacobs, apparently basing his observation wholly on frequency of citation, nominated Cooley as "the principal contributor to the cause of constitutional laissez-faire in the era following the Civil War." JACOBS, supra, at 27. Those who later saw ratification of the Fourteenth Amendment as a conspiracy to secure property rights against socialism regarded Cooley as one of the conspirators, his treatise being the primary evidence. See Howard J. Graham, The "Conspiracy Theory" of the Fourteenth Amendment, 47 Y ALE L.J. 371 (1938); (discussing the "conspiracy theory" generally); see also Janies W. Hurst, THE Growth of AMERICAN LAw: The Law Makers 338 (1950) (criticizing Cooley's "doctrinal inventiveness" in formulating the "freedom of contract and its haven under "property' in the Fourteenth Amendment"); Joel E. Paschal, Mr. Justice Sutherland: A Man Against the STATE 9 (1951) (pointing to Cooley as the "Spencerian disciple" who most influenced the young Justice Sutherland).

More balanced in their presentation of Cooley are Jones, supra note 2 and Thomas G. Barnes, Introduction to Thomas McInTYRe COOLEY, Constitutional Limtrations (Legal Classics editions, 1987) (1868). See also BASKERVIILE, supra note 230; FRIEDMAN, supra note 62, at 545 (calling Twiss' assertion that Cooley's text directly countered Marx's "certainly an exaggeration"); HowARD GLLIMAN, The Consttiution Besieged: The Rise and Demise of Lochner Era Police Powers Jurisprudence 55-59 (1993) (arguing that Cooley's laissez-faire views have been misunderstood by historians); DAvID M. Gold, The Shaping of Nineteenth-Century Law: John Appleton and Responsible IndividuALISM 139 (1990) (arguing that Cooley"s reputation as a laissez faire jurist is flawed, because his "constitutionalism was grounded not in economic theory . . . but in a Jacksonian fear of special corporate privilege"); William E. Nelson, The Fourteenth Amendment: From Polticical Principle to JudiCIAL DOCTRINE 179-80 (1988) (portraying Cooley as a centrist among his fellow late nineteenth century constitutional commentators); WIILIAM E. Nelson, THE ROOTS OF AMERICAN BuREAuCracy, 18301900 , at 95 (1982) (characterizing Cooley's constitutional theories as antagonistic to all concentrations of private economic power put to selfish ends); G. EDWARD WhITE, The AMERICAN Judicial TRAdition: Profiles of Leading American Judges 121 (expanded ed. 1988) (characterizing Cooley as "simultaneously an opponent of concentrated wealth and one of the intellectual founders of legal justifications for unregulated capitalism"); Michael Les Benedict, Laissez Faire and Liberty: A Reevaluation of the Meaning and Origins of Laissez Faire Constitutionalism, 3 L. \& Hrst. Rev. 293 (1985); Joan C. Williams, The Constitutional Vulnerability of American Local Government: The Politics of City Status in American Law, 1986 WIs. L. Rev. 83, 138 (arguing that Cooley's constitutional theories resulted from apprehension about any exercise of governmental power).

250. WhITE, supra note 249 , at 151. 
characterization resting on a mere handful of the thousands of opinions he wrote.

Holmes may have been more "liberal" than Cooley in the diction of political theorists who contrast the contractarian and imputedly "liberal" ideology of John Locke and other authors of the Enlightenment, on one hand, with the mercantilist or Whig, and imputedly "conservative," ideology of Edmund Burke, on the other. ${ }^{251}$ Holmes was more Lockean and less Burkean than Cooley. Yet the Locke-Burke distinction is often at odds with the understanding of the laity outside the academy, who might regard Locke's conception of individual rights as protective of vested interests, and thus conservative, while seeing Burke's conception of duties to society as an imposition on vested rights, and thus liberal. In that popular locution, Holmes was no liberal, but Cooley was. 252

Cooley thought of himself as a conservative in the Burkean sense. But his conservatism was that of one who admired democratic institutions and conceived of the judicial task as the protection of those institutions. ${ }^{253}$ "Here," James Fenimore Cooper wrote in describing the culture from which Cooley emerged, "the democrat is the conservative, and, thank God, he has something worth preserving." 254 This conservatism was communitarian, and it was communitarian duty that Cooley had in mind when he told his students that "[ $t]$ he lawyer is and should be conservative." $255 \mathrm{He}$ articulated his conservatism in 1878 to an audience at Johns Hopkins University:

There are two senses in which one may be in advance of his age; the one useful, the other mischievous. The man who fully appreciating what the world is now and his competency to enlighten and benefit it, devotes himself to the task of doing so and waits patiently for the germination of the seed he sows, content that others shall reap the harvest which no hotbed forcing would ripen for his own enjoyment-this man may justly be called in advance of his age and praised for his labors as such, for by such labors may great reform be wisely and safely brought about. But the man more commonly praised as being in advance of his age is of a different sort. He is the man who, scorning the slow process of preparation, will insist upon forcing upon the world now what only a patient training of generations can fit it for; who sees in every people a

251. See, e.g., Alexander M. Bickei, The Morality of ConSENT 3-30 (1975); Hartz, supta note 111 , at 145-77.

252. John Rawls has elaborated a political theory rooted in Burke's egalitarian concept of justice. See JoHN RAwLS, POLITICAI LIBERAIISM (1993). Nowhere in that tightly reasoned work, however, does Rawls explain his use of the term "liberal" to describe his theory. He acknowledges the historical origins of his theory to be in the Reformation and thus related to what Judith Shklar has described as "the liberalism of fear." JUDITH N. SHRLAR, ORDINARY VICES 5 (1984). Such "liberalism" is a commitment to tolerance as a preventive of mutual destruction. See id. Burke, it seems clear, was perhaps the quintessential "liberal of fear," and there is no reason to suppose that he would have contested Rawls" abstractions. Rawls and Burke might reach different conclusions with respect to specific problems, but one could not accurately forecast those differences on the basis of their commitments to abstract theory, and certainly not on the basis of labeling one liberal and the other conservative.

253. See, e.g., COOLEY, supra note 9 , at 3.

254. FENIMORE-COOPER, supra note 65, at 99 (1834).

255. Address by Hon. Thomas M. Cooley, and Poem by D. Bethune Duffield, Esq., on the Dedication of the Law Lecture Hall of Michigan University (Oct. 1, 1863). 
present adaptability to his ideal, and who scoffs at all experience that does not conform to his preconceived notions as to what, under the circumstances, should have taken place. Such a man naturally ventures upon any experiment in government with no misgivings respecting the result, and if it proves calamitous, it is enough for his self complacency that he can say it was because he was too greatly in advance of his age. If he suffers with those who blindly followed his leading, he looks for and will think he deserves the martyr's crown as one who has given himself for the good of the world. But as all premature experiments in government are likely to have reactionary influence, we shall believe the world seldom wrong in withholding its praise from such persons. To usefully lead an age as statesman one must be of it, must recognize its prevailing ideas and sentiments and take note of and respect such obstacles as these present to any great and sudden change. If the age is not yet prepared for his ideal, he will content himself with what is practical and attainable instead of forcing upon it something which could be better only if voluntarily accepted. ${ }^{256}$

Cooley was, as a judge, conservative in just the sense he defined. When he exercised constitutional prerogatives, it was not to author "experiments in government." He was generally disposed to do "what was practical and attainable." But he also authored less cautious words:

"The constitution as it is and the Union as it was" can no longer be the motto and the watchword of any political party. We may preserve the constitution in its every phase and every letter, with only such modification as was found essential for the uprooting of slavery; but the Union as it was has given way to a new Union with some new and grand features, but also with some engrafted evils which only time and the patient and persevering labors of statesmen and patriots will suffice to eradicate. ${ }^{257}$

In 1889 , he counseled the North Dakota Constitutional Convention against drafting a text that would too tightly confine the state's legislature and disable it from regulating "engrafted evils."258 Holmes saw little that was "new and grand" in the "new Union" and doubted that even "the patient and persevering labors of statesmen and patriots" could eradicate evil.259 Yet he and Cooley would both have agreed that in drafting constitutional texts, "[t]ight will tear; [w]ide will wear."260

Cooley's Jacksonian view of courts and the legal profession as instruments of popular democracy was different in fundamental respects from the aristocratic view of courts and the legal profession as an oligarchy radiating out from

256. Lecture I, supra note 193, at 9-10. Cooley offered as an example of an improvident futurist John Elliott, the Puritan apostle to the New England Native Americans. See id. at 10-11. Elliott supposed that having learned the catechism, a tribe was ready to hold elections.

257. COOLEY, supra note 18 , at 371 .

258. His remarks are quoted by Alan R. Jones, Thomas M. Cooley and the Michigan Supreme Court: 1865-1885, 10 AM. J. LEGAL HIST. 97, 121 (1966).

259. For Holmes' view, see Oliver W. Holmes, Ideals and Doubts, 10 ILL. L. Rev, 1 (1915) (discussing trends in legal thought).

260. Francis Lieber, Legal and Political. Hermeneutics 195 n.* (William G. Hammond ed., St. Louis, F.H. Thomas \& Co., 3d ed. 1880). For an earlier expression of the same point, see BRACKENRIDGE, supra note 64 , at 45 . 
Beacon Hill, the Harvard Law School, and what came to be known as the Ivy League. Holmes was an early and exceptionally disinterested and restrained oligarch, but an oligarch nonetheless. Nevertheless, as we have seen, these deep differences had only modest bearing either on their conceptions of the judicial role in constitutional litigation or their likely decision in most cases.

\section{Constitutional Litigation In MrChigan}

To understand the Jacksonian view that was subsiding in November 1886, it will repay us to take a few pages to review the work of Cooley's court. Without pausing long to speculate whether Holmes might have decided differently, let us examine a few cases in which Cooley undertook to express the "common thoughts of men." These cases reflect both Cooley's intent and his confidence that he knew the "common thoughts" and that they were the Jacksonian thoughts prevailing in his own mind.

Frederick Grimke suggested as one justification for the election of judges that elected judges are more courteous than appointed ones. ${ }^{261}$ So it may be. Soon after his election to the court in 1865, Cooley became known to the Michigan bar as an exceptionally attentive listener and one who would respond forthrightly in his opinions to the arguments advanced by losing counsel. ${ }^{262} \mathrm{He}$ was re-elected in 1869 and 1877, but failed in his 1885 bid. 263

Cooley spent his 20 years on the bench in a time denominated by a leading chronicler as a "search for order." 264 During this period, America was responding to the destabilizing effects of an epic war in which a million young men, constituting at least a fifth of those of military age, had been killed or maimed. The popular hope for restored stability in the social order was paralleled by a hope widely shared among lawyers for predictability in the law. ${ }^{265}$ Cooley understood and shared in this anxiety, and it probably contributed to his preference for "safe" judges. Several years after his defeat at the polls and retirement as a judge, Cooley found occasion to reassure the electorate and the bar that the legal process in his time on the bench had produced predictable results. ${ }^{266}$

Nevertheless, Cooley always recognized that his judicial office was a political one and he did not recoil from giving political reasons for judicial decisions. ${ }^{267}$ When he expressed political values, he often invoked the "equal

261. See GrIMKE, supra note 108 , at 457.

262. See Rogers, supra note 2 , at 205.

263. See George Edwards, Why Justice Cooley Left the Bench: A Missing Page of Legal History, 33 WAYNE L. REV. 1563 n.1 (1987).

264. ROBERT H. WIEBE, THE SEARCH FOR ORDER: 1877-1920 (1967). Wiebe begins his account with the recovery from the depression of 1873 and the aftermath of the Grant Administration. He might reasonably have commenced with the end of the Civil War.

265. See WHITE, supra note 249 , at 114.

266. See Thomas M. Cooley, The Uncertainty of the Law, 22 AM. L. REv. 347, 368 (1888). To this reader, the reassurance is not especially convincing. Although this was one of Cooley's more pedestrian works, the theme is echoed by later authors. See, e.g., KARL N. LLEWELlyN, THE Common Law TRadition: Deciding Appeals (1960).

267. This reasoning was not so extraordinary as some twentieth century observers may suppose. See, e.g., Harry N. Scheiber, Instrumentalism and Property Rights: A Reconsideration of American 
rights" doctrines of the Barnburners embodied in the culture brought to Michigan from western New York, values that, as we have seen, he shared with most of the people of Michigan. His behavior was controlled by a professional discipline requiring faithful attention to the mandates of legislation and to the text of the 1850 Michigan Constitution, as understood by his political constituents. $\mathrm{He}$ read both constitutional and statutory texts in light of the cultural context from which they arose, namely, as events in the social history of Michigan. He did not deny the possibility that constitutional language might over time change meaning, but his historicism and professional self-restraint dictated that such changes originate in cultural change already reflected in the values and moral aspirations of the people. In this view, genuine cultural change ought to reflect the understandings of a broadly representative legal profession, and not merely a change in the personnel of the court, or in the personal ambitions of judges to implement their idiosyncratic, subcultural, or class preferences. ${ }^{268}$

One of Cooley's first judicial opinions in 1865 seemed admirably professional to his constituents. He held that the state's election laws violated the Michigan Constitution's residence requirements for voters. ${ }^{269}$ The invalidated law was enacted to permit voting by soldiers on military duty outside the state, a purpose warmly approved by the people of Michigan, as well as by Cooley and the other members of his court, all of whom were deeply committed to the Union cause. 270 Because the absentee soldiers were predominantly Republicans, the decision was especially unwelcome to those who supported Cooley's election to the court. Moreover, absentee soldiers elected Republican legislators who held key votes in certain legislative decisions. ${ }^{271}$

Cooley explained that the text of the Constitution was clear and to disobey it "in times like these" would loosen "the anchor of our safety."272 The judiciary, he said, should do nothing to "bend the meaning of words to meet unexpected emergencies." 273 Judges had to obey "plain meanings" of constitutional dictates. Times like these required the court to give no one occasion to question its fidelity to law. ${ }^{274}$

Cooley did not add that his interpretation was constrained from advancing his own interests or the obvious interests of his political allies, for that was the difficulty he faced. His political constituents would have readily identified such a holding as self-serving manipulation. He surely knew that many Americans had been offended in the past by seemingly partisan judicial decisions, even by the Marshall Court. 275 Alas, no Michigan judges could remain wholly

\footnotetext{
"Styles of Judicial Reasoning" in the 19th Century, 1975 WIs. L. REv. 1, 3 (explaining that many legal professionals believed courts should change the law to reflect social policy).

268. For general support for these propositions, see COOLEY, supra note 9.

269. See People v. Blodgett, 13 Mich. 127, 162 (1865).

270. See JoNEs, supra note 2 , at 169.

271. See id. at 170 (citing People v. Mahaney, 13 Mich. 481 (1865)).

272. Blodgett, 13 Mich. at 173.

273. Id.

274. Similar sentiments were expressed earlier by Lincoln. See Lincoln, supra note 193, at 112.

275. See G. Edward White, The Marshail Court and Cultural Change: 1815-1835, at 93444 (Paul A. Freund \& Stanley N. Katz eds., 1988).
} 
disinterested in the outcome of the case, for all had political allegiances of one stripe or another. Holmes, as an appointed judge with no political constituents, might possibly have reached a different result, for he could have done so without fear that his decision would be regarded as corrupt. While the state constitution limited the franchise to those in residence in Michigan, a more apolitical judge might well have concluded that soldiers performing their public duty to the state of Michigan by serving in its militia were "present" in Michigan within the "plain meaning" of the text.

Cooley's strict fidelity to constitutional text in this circumstance proved to be good politics. The decision led the Democrats in 1869 seriously to consider supporting his re-election. Even though the decision caused Republicans to complain that while they did the electing, "the Democrats got all the decisions," 276 many Republicans may have taken special pride in the integrity of their court.

While the voting rights decision exemplified Cooley's obedience to "plain meaning" even when it yielded personally unwelcome results, he did not adhere strictly to "original intent"277 as the source of constitutional meaning. He was quite willing to project the constitutional purpose of 1850 to unforeseen circumstances and thus accommodate constitutional text to discernible contemporary mores, but only where in his judgment the text allowed such accommodation.

For example, the 1850 Michigan Constitution had authorized the state to provide for free "primary schools."278 In 1874, a case presented the question whether the legislature could authorize a school district to collect taxes to support a high school teaching non-elementary subjects such as Latin. ${ }^{279}$ Cooley held that it could, in part by reviewing the history of public education in Michigan and praising the foresight of the founders of 1850 in authorizing the state to furnish "the poorest boy of the state" with instruction as good "as the rich man can furnish for his children with all his wealth."280 He found that the constitution imposed no restriction on primary schools "in the branches of knowledge which their officers may cause to be taught, or the grade of instruction that may be given, if their voters consent in regular form to bear the expense and raise the taxes for the purpose."281 Cooley also found it pertinent that the constitution required the legislature to create and support a public university; it would have been irrational for the framers of 1850 to authorize and even require elementary and higher education while forbidding the use of public revenue to support interconnecting secondary education.

276. JONEs, supra note 2 , at 172 .

277. Cf. Antonin Scalia, Originalism: The Lesser Evil, 57 U. CIN. L. Rev. 849, 851-52 (1989) (giving a modern jurist's explanation of the "originality" approach to constitutional interpretation).

278. МrCH. Const. of 1850 , art. XIII, $\S 4$.

279. See Stuart v. School Dist. No. 1 of Kalamazoo, 30 Mich. 69 (1874).

280. Id. at 80 (quoting superintendent Pierce's report recommending that the legislature establish a public school system).

281. Id. at 84 . 
This case contrasts with the voting rights case in its method of interpreting constitutional texts. An important difference lies in the fact that Cooley and his political allies had no stake in the secondary schools case: Since there was no risk that his decision would be seen as self-dealing, he was more free to interpret the text. This was, indeed, an easy case; it is hard to imagine an American court reaching a contrary result. It may be seen as a good example of the inadequacy of "plain meaning" or "original intent" as overriding principles of interpretation.

Other examples of Cooley's interpretative skills exhibit his commitment to democratic institutions. For instance, in a series of lectures given to an audience in Baltimore, Cooley offered an explanation of democratic conservatism in which he advanced the idea of constitutional home rule for local government, ${ }^{282}$ an idea of some novelty in 1878 . The idea would become an article of faith for twentieth century Progressives. ${ }^{283}$ In presenting it, Cooley was "in advance of his age," but his aim was, as Cooper put it, to "conserve democracy," and the institutions of decentralized popular self-government.

As a judge, Cooley supposed that the Michigan legislature shared his predisposition favoring local self-government. Whether or not this supposition was warranted, he was careful not to insist on his position, leaving it open to the legislature to reject. An illustrative case is People v. Hurlbut. ${ }^{284}$ The 1850 Michigan constitution in pertinent part provided that "[j]udicial officers of cities and villages shall be elected, and all other officers shall be elected or appointed, at such time and in such manner as the legislature may direct."285 The Common Council of Detroit had designated sewer and water commissioners, one of whom was Hurlbut. The legislature thereafter created a Board of Public Works for Detroit, with powers formerly exercised by Hurlbut, and it designated other persons to serve on that board. Pursuant to that enactment, the Attorney General of Michigan brought an action to remove Hurlbut from his now disabled office. Cooley's court held for the Attorney General and removed Hurlbut, but it interpreted the statute in question as one giving the legislature the power to make only provisional appointments to the Board of Public Works, thus leaving the Common Council free to make permanent appointments to that Board, perhaps even of Hurlbut himself. 286

This decision embodied an aggressive interpretation of the controlling legislation, one that could be said to have twisted its apparent meaning. The statutory text expressed rather clearly a legislative purpose to displace the officers appointed by the Common Council. However, the Cooley court returned the

282. See Lectures I-VI, Johns Hopkins University (1878) (unpublished manuscripts in Box 1, Cooley Collection, Bentley Library, University of Michigan).

283. Cooley's position on home rule is examined in Williams, supra note 249 , at $137-49$. See also Edwin A. Gere, Dillon's Rule and Cooley's Doctrine: Reflections of the Political Culture, 8 J. URB. Hist. 271, 280 (1982). Williams, on no evidence, attributes Cooley's support for local government to his alleged desire to disable state legislatures. See Williams, supra note 249, at 146-47.

284. 24 Mich. 44, 93 (1871). For background, see Jones, supra note 258, at 115-17 (discussing Cooley's effort to balance his support for local government with his belief in judicial restraint).

285. Mich. Const. of 1850, art. XV, § 14.

286. See Hurlbut, 24 Mich. at 111-12. 
issue to the legislature with a cautionary expression of concern that the legislature had perhaps overlooked public values of constitutional import. ${ }^{287}$ If the legislature revised the Board of Public Works legislation to make it explicit that the Board of Public Works, and not the Common Council, appointed sewer and water commissioners, the court would then have been forced to decide an issue that it had previously evaded by its strained interpretation of the statute.

If thus forced by explicit legislative re-enactment to reconsider its decision, the later court might have deferred to the superior political station of two legislatures and relied on the most obvious meaning of the constitutional text quoted above - that the mode of selection of the members of the Board is a matter for unfettered legislative choice. But Cooley's opinion left open the possibility that a later court could base a different decision on a different principle. Cooley located in the interstices of the Michigan Constitution of 1850 a general but implied constitutional preference for local government. He argued that it was implicit in the constitutional language quoted that the officers of a local board of public works should be either elected or appointed, as the legislature might choose, but only by local voters or their locally elected representatives, not by representatives elected by the voters of some larger region such as the state as a whole, or appointed by a potentate in distant Lansing. ${ }^{288}$ It might, he suggested, be unconstitutional for the voters of the state to presume to elect a mayor of Detroit.

In justifying this inference, Cooley did not rely on case law, but on the whole range of literature defining local self-government as an essential element of the English legal tradition, and even more so of the American. In particular, he relied upon Jefferson, Tocqueville, and Lieber. Francis Lieber, no Jacksonian, emphasized the importance of decentralization to republican government, especially in facilitating participation by citizens in public decisions most affecting their own interests. ${ }^{289} \mathrm{He}$ also viewed the right to jury trial as part of the same fabric, woven to assure every man an equal voice in government. Cooley wrote in Lieber's terms:

[W] hen the state reaches out and draws to itself and appropriates the powers which from time immemorial have been locally possessed and exercised, and introduces into its legislation the centralizing ideas of continental Europe . . . we seem forced back upon and compelled to take up and defend the plainest and most primary axioms of free government, as if even in Anglican liberty, which has been gained step by step, through extorted charters and bills of rights, the punishment of kings and the overthrow of dynasties, nothing was settled and nothing established. 290

287. See id. at 110-12; cf. Alexander M. Bickel \& Harry H. Wellington, Legislative Purpose and The Judicial Process: The Lincoln Mills Case, 71 HARv. L. REv. 1, 34, 38 (1957) (discussing when the Supreme Court asks Congress to reconsider constitutional problems in legislation).

288. See Hurlbut, 24 Mich. at 109.

289. See Francis Lieber, On Civil Liberty and Self-Government (Theodore D. Woolsey ed., Philadelphia, J.B. Lippincott \& Co., 3d ed. 1853).

290. Hurlbut, 24 Mich. at 108. 
"Some things," Cooley said, "are too plain to be written."291 Yet he added breathlessly:

If this charter of state government which we call a constitution, were all there was of constitutional command; if the usages, the customs, the maxims, that have sprung from the habits of life, modes of thought, methods of trying facts by the neighborhood, and mutual responsibility in neighborhood interests, the precepts which have come from the revolutions which overturned tyrannies, the sentiments of manly independence and self-control which impelled our ancestors to summon the local community to redress local evils, instead of relying upon king or legislature at a distance to do so-if a recognition of all these were to be stricken from the body of our constitutional law, a lifeless skeleton might remain, but the living spirit, that which gives it force and attraction, which makes it valuable and draws to it the affections of the people, that which distinguishes it from the numberless constitutions, so called, which in Europe have been set up and thrown down with in the last hundred years, many of which, in their expressions, have seemed equally fair and to possess equal promise with ours, and have only been wanting in the support and vitality which these alone can give-this living and breathing spirit, which supplies the interpretation of the words of the written charter, would be utterly lost and gone. ${ }^{292}$

One might guess from the shrill tone of this opinion that Cooley was on soft ground, as indeed he was. The conventional view, as Cooley acknowledged in his treatise, ${ }^{293}$ was that local government is a mere creature of the state, having no status independent of the legislature in the absence of explicit constitutional provisions conferring "home rule" powers. Nevertheless, he apparently persuaded the Michigan legislature for the moment; it revised the statute to provide that members of the Board of Public Works be appointed by the Detroit Common Council. ${ }^{294}$

Cooley interpreted similarly another statute imposing state control on local matters. ${ }^{295}$ The legislature created a Park Commission for Detroit as part of the state government. The Commission identified land suitable for an urban park and sought to compel the Common Council elected by the people of Detroit to buy and improve it at local expense. ${ }^{296}$ The Supreme Court of Michigan, Cooley concurring, upheld the right of the Common Council to refuse the measure and interpreted the statute narrowly to avoid conflict with the constitutional values of local self-government. ${ }^{297}$ Cooley's court later invoked the same principle of construction to shield local communities from a regional drain commissioner's efforts to require them to build drains at local expense to serve other

291. Id. at 107.

292. Id.

293. See Cooley, supra note 9 , at 192.

294. 1873 Mich. Pub. Acts 392.

295. See Park Comm'rs v. Mayor of Detroit, 29 Mich. 343 (1874).

296. See id. at 353.

297. See id. 
neighboring communities. ${ }^{298}$ In none of these cases was there a conflict between local government and an office of state government having statewide jurisdiction and thus the full political backing of the legislature. Justice Cooley, for the court, reasoned that in such matters, "[t]he motive for outside interference [by the state] will very likely be something besides a desire to do good to a community in which the parties interfering have no personal interest ...."299 The legislature, he concluded, should (in the absence of the most explicit language expressing a statewide policy or establishing a statewide program) respect the right of a local community to control local affairs. ${ }^{300}$

In these matters of local self-government, Cooley likely succeeded in expressing the prevailing values of the people of Michigan, ${ }^{301}$ and perhaps also those of the legal profession of Michigan, although the latter seems less clear. Cooley and his court also anticipated the Home Rule Movement that inserted into many state constitutions explicit provisions limiting the powers of state legislatures to regulate or burden local communities. That movement first surfaced in Missouri in 1875 and was fostered at the turn of the century by Progressives. ${ }^{302}$ Although the Supreme Court of the United States later held that institutions of local government are not protected from the state by the federal Constitution, ${ }^{303}$ the Court has recognized the constitutional value of local self-government in some other applications of the Fourteenth Amendment. ${ }^{304}$

Cooley also employed his interpretative art to protect such values favored by the Barnburners that he found embedded in the interstices of the Michigan constitution. For example, he used the technique of interpreting legislation to avoid a constitutional issue in an early school segregation case. In 1869, Cooley's court ordered the Detroit Board of Education to admit black children to schools previously restricted to white children. ${ }^{305}$ Public schools in Detroit had been segregated from the time when black children first began to appear in the community. The legislation creating the Detroit schools and governing their operation was silent on matters of attendance. The general school laws had been regarded as inapplicable to the Detroit schools since these schools were the subject of a separate body of legislation. However, an 1867 amendment to

298. See Robertson v. Baxter, 57 Mich. 127 (1885); see also Allor v. Board of Auditors, 43 Mich. 76 (1880) (narrowly construing the Police Act of Detroit so as not to infringe upon the powers of local police officers).

299. Board of Park Comm'rs v. Common Council, 28 Mich. 227, 241 (1873).

300. See id. at 248 .

301. Cf. JONES, supra note 2 , at 172.

302. For an account of the present status of Home Rule provisions, see David L. Callies, Home Rule, in 1 Local Government Law (C. Dallas Sands, Michael E. Libonati \& John Martinez eds., 1994). For an analysis of the judicial role in enforcing such provisions, see Terrance Sandalow, The Limits of Municipal Powers Under Home Rule: A Role for The Courts, 48 MinN. L. REv. 643, 658 (1964).

303. See Hunter v. City of Pittsburgh, 207 U.S. 161, 179 (1907).

304. See, e.g., San Antonio Indep. Sch. Dist. v. Rodriguez, 411 U.S. 1 (1973) (holding that a school system that insures local control of schools holds up under equal protection rationality review); cf. Milliken v. Bradley, 418 U.S. 717 (1974) (limiting a court's ability to impose remedies for school segregation that cut across school district lines).

305. See People v. Board of Educ., 18 Mich. 399 (1869). 
the laws generally governing schools in the state provided somewhat enigmatically that local schools should be open all residents of any district. ${ }^{306}$ Justice Campbell argued that this clause was (like the rest of the general school code) inapplicable to Detroit schools and did not, in any case, address issues of racial assignment. ${ }^{307}$ But the majority, led by Cooley, rejected Campbell's interpretation of the statutes and held that the Detroit practice violated the amended state law. 308 Cooley also noted slyly that since.the statute applied, "[i]t does not become important to consider what would otherwise have been the law,"309 thus implying the possibility that the practice of the Detroit schools was constitutionally proscribed. He refrained from quoting his own recently published text in which he claimed that "[e]quality of rights, privileges, and capacities unquestionably should be the aim of the law." 310 Nor did he refer to the Equal Protection Clause of the recently adopted Fourteenth Amendment to the Constitution of the United States. Had he pursued the avoided constitutional issue even in dicta, his court's decision would have been a precedent of some weight favoring the dissent in the 1896 decision of the Supreme Court of the United States in Plessy v. Ferguson. ${ }^{311}$ And he might have enshrined his name in the history of the civil rights movement.

The constitutional issue that Cooley avoided in so deciding the school segregation case was not raised by any explicit provision of the Michigan constitution. But Cooley's treatise had stated it to be settled law under diverse state constitutions that legislatures cannot lawfully enact "unequal or partial" legislation. "Equality of rights, privileges, and capacities unquestionably should be the aim of the law ... [and] [t]he State, it is to be presumed, has no favors to bestow, and designs to inflict no arbitrary deprivation of rights . ..."312 These are among the few statements in the treatise that are not heavily documented. Perhaps this gloss was warranted, but Cooley's action in the case confirms that he was not always a close textualist.

Cooley also favored freedom of expression, another Barnburner tenet. Perhaps most prescient of Cooley's constitutional opinions was his dissent in Atkinson v. The Detroit Free Press. ${ }^{313}$ Atkinson had been a member of the Detroit Board of Trade. The Free Press reported that Atkinson, as a member of the Board, was engaged in activity that it deemed fraudulent. Atkinson sued the publisher and recovered a judgment for libel that the Supreme Court of Michigan affirmed in an opinion by Justice Campbell. Cooley filed a long

306. See id. at 408 .

307. See id. at 415 .

308. See id. at 414.

309. Id.

310. COOLEY, supra note 9, at 393. However, in this text he also acknowledged the force of a state constitutional provision limiting the franchise to whites. See id. at 394. The Fifteenth Amendment to the Constitution of the United States trumped this Michigan constitutional provision, but not until 1870.

311. 163 U.S. 537, 557 (1896) (Harlan, J., dissenting); cf. Strauder v. West Virginia, 100 U.S. 303 (1880) (holding that the Equal Protection Clause precludes states from restricting jury service to white persons).

312. COOLEY, supra note 9, at 393.

313. 46 Mich. 341,355 (1881). 
dissent, arguing that a newspaper commenting on the conduct of a public figure should be held liable only on proof of malice. ${ }^{314} \mathrm{He}$ supported his position by inference from provisions of the Michigan constitution protecting freedom of expression, a move that prefigured the 1964 decision of the Supreme Court of the United States in New York Times v. Sullivan. ${ }^{315} \mathrm{He}$ emphasized the need for integrity on the Board of Trade and the duty of the press to expose moral shortfalls in the performance of duty by its members. ${ }^{316}$ He concluded:

If such a discussion of a matter of public interest were prima facie an unlawful act, and the author were obliged to justify every statement by evidence of its literal truth, the liberty of public discussion would be unworthy of being named as a privilege of value. It would be better to restore the censorship of a despotism than to assume to give a liberty which can only be accepted under a responsibility that is always threatening and may at any time be ruinous. ... [E]very man of common discernment who observes what is taking place around him, and what influences control public opinion, cannot fail to know that reputation is best protected when the press is free. ${ }^{317}$

Although prescient, Cooley's reasoning in Atkinson can be questioned. His suggestion that prior restraint might be less objectionable than the imposition of tort liability for defamation has been roundly rejected by the Supreme Court of the United States. ${ }^{318}$ And one "who observes what is taking place around him and what influences public opinion" in 1997 might possibly disagree that "reputation is best protected when the press is free." Had Cooley encountered modern media and the disintegration of modern political coverage into a seemingly unbroken series of innuendos that degrade almost all who seek public office, he might have wondered whether media free of the shackles of defamation law is the best protection either of honest reputation or of open public discussion. Perhaps had he decided Atkinson a century later, he would have led the way in an opposite, or at least a different, direction. In any case, Cooley's decision again reflected his intent to interpret the constitutional text as an expression of Jacksonian Barnburner values.

Only once in twenty years did Cooley's court frontally challenge the Michigan legislature so as to provoke serious controversy. This confrontation was yet another occasion when Cooley detected Jacksonian premises in the interstices of the constitutional text. The case involved public financial assistance to

314. See id. at 376-77.

315. 376 U.S. 254 (1964).

316. Cooley's views in this regard appear to have made an impression on the court. The next year, the court upheld the press' privilege against a claim by a judge whom the newspaper had accused of confining a man without a charge and setting excessive bail. See Miner v. The Detroit Post \& Tribune Co., 49 Mich. 358 (1882).

317. Atkinson v. Detroit Free Press Co., 46 Mich. 341, 383 (1881); cf. Harry Kalven, The New York Times Case: A Note on The "Central Meaning of the First Amendment" 1964 Sup. CT. REv. 191, 205 (arguing that seditious libel laws threaten democracy by suppressing criticism of government). But in MacLean v. Scripps, 52 Mich. 214 (1883), Cooley joined in affirming a judgment in favor of a professor of medicine accused by the press of adultery. In his opinion denying a rehearing to the publisher, he claimed that "[n]o court has gone further than has this in upholding the privilege of the press, and very few so far." Id. at 253.

318. See Near v. Minnesota, 283 U.S. 697 (1931) (holding that the chief purpose of the First Amendment is to prevent prior restraints on publication). 
privately owned railroads. ${ }^{319}$ Cooley's decision was widely heralded by the people of Michigan ${ }^{320}$ even as it deeply distressed railroads and investment bankers. ${ }^{321}$ The decision was perhaps more quaint than prescient, although a postmodern generation, chafing over the expenditure of hundreds of billions of tax dollars to repay individuals for improvident investments made through excessively insured savings and loan institutions, might see the issue in a light favorable to Cooley. So might those who have lost their jobs in plant closings caused by subsidies paid by distant state and local governments to employers as inducements to relocate; or taxpayers whose taxes are used for the benefit of private profit-seekers such as the operators or professional sports franchises; or fans whose teams are moved to secure the benefits of a public subsidy.

The town of Salem, Michigan had pledged its credit to aid construction of the Detroit \& Howell Railroad in consideration for a promise by the road to provide service to the town. The road was constructed in reliance upon that and other such pledges. Many towns in Michigan, indeed thousands in the United States, had made such pledges under the threat that their failure to make the commitment would result in a denial of rail service and the almost certain atrophy of the local economy. In 1864, the legislature, at the insistence of railroads and after sustained dispute signaling widespread popular opposition, ${ }^{322}$ authorized municipalities such as Salem to levy taxes to aid railroads. In 1870, the Detroit \& Howell Railroad sued the town of Salem to compel it to honor its promise of support by issuing bonds to be retired from the town's future tax revenues. ${ }^{323}$ The Supreme Court of Michigan denied relief, holding the 1864 legislation unconstitutional because any payment of interest or principal on such bonds would entail use of public revenue for a private purpose. ${ }^{324}$ Since the municipalities were unable to pay interest or principal, it would be fraudulent to issue bonds as demanded by the road. ${ }^{325}$

The opinion of the court first distinguished public subsidies from the exercise of the power of eminent domain. "It is true," Justice Cooley wrote,

that a railroad in the hands of a private corporation is often spoken of as a public highway, and that it has been recognized as so far a public object as to justify the appropriation of private property for its construction; but this fact does not conclusively determine the right to employ taxation in aid of the road in the like case. Reasoning by analogy from one of the sovereign powers of government to another, is exceedingly liable to deceive and mislead. An object may be public in one sense and for one purpose, when in a general sense and for other purposes, it would be idle and misleading to apply the same term. All

319. People ex rel. Detroit \& Howell R.R. v. Township Bd. of Salem, 20 Mich. 452 (1870) thereinafter Salem].

320. See JONES, supra note 2 , at $179-80$.

321. See Jones, supra note 258, at 101-06.

322. A Republican Governor had vetoed such legislation in 1866 and 1867 . Constitutional revision was proposed in 1868 to authorize such aid, and the revision was defeated by vote of the people. See JONES, supra note 2, at 174.

323. See Salem, 20 Mich. at 452.

324. See id. at 494.

325. See id. 
governmental powers exist for public purposes, but they are not necessarily to be exercised under the same conditions of public interest. ...

... [The railroads'] resemblance to the highways which belong to the public, which the people make and keep in repair, and which are open to the whole public to be used at will, and with such means of locomotion as taste, or pleasure, or convenience may dictate, is rather fanciful ... . [Railroads] are not, when in private hands, the people's highways; but they are private property, whose owners make it their business to transport persons and merchandise in their own carriages, over their own land, for such pecuniary compensation as may be stipulated. . . . [Their] business [ ] has indeed its public aspect inasmuch as it accommodates a public want; ... . But it is not such a purpose [so different from] the opening of a hotel, the establishment of a line of stages, or the putting in operation of a grist mill ...326

The court then proceeded to give restrained expression to the received doctrine of "equal rights" embodied in the Michigan Constitution of 1850:

We concede ... that religion is essential . . . yet we prohibit the State from burdening the citizen with its support. ... Certain professions and occupations in life are also essential, but we have no authority to employ the public moneys to induce persons to enter them. ...

...

... However great the need in the direction of any particular calling, the interference of the government is not tolerated, because though it may be supplying a public want, it is considered as invading the domain that belongs exclusively to private inclination and enterprise.

...

... [T] dise discrimination by the State between different classes of occupations, and the favoring of one at the expense of the rest, whether that one be farming or banking, merchandising or milling, printing or railroading, is not legitimate legislation, and is an invasion of that equality of right and privilege which is a maxim in state government. ... [W] hen the State once enters upon the business of subsidies, we shall not fail to discover that the strong and the powerful interests are those most likely to control the legislation, and that the weaker will be taxed to enhance the profits of the stronger. ${ }^{327}$

This decision was "the great news of the summer" of 1870.328 The Governor heatedly reported that it destroyed the value of millions of dollars of bonds already issued by Michigan towns other than Salem, some of them in the hands of third parties, and he asked the legislature to do something to protect the innocent investors. Railroad men were apoplectic. The decision was criticized as contrary to the great weight of precedent, which it was, and lacking footing in any explicit constitutional text, which it was. ${ }^{329}$ But the decision was also

326. Id. at $477-79$.

327. Id. at $483-87$.

328. JONEs, supra note 2, at 181 n.41.

329. See, e.g., Charles Kent, Municipal Subscription and Taxation in Aid of Railroads, 9 AM. L. Reg. 649 (1870); Note, 7 AM. L. Rev. 126 (1870). The Supreme Judicial Court of Maine reached a similar result relying upon the explicit language of the Maine Constitution forbidding takings without compensation. See Allen v. Jay, 60 Me. 124 (1872); see also Hansen v. Vemon, 27 Iowa 28 (1869) 
defended as a prudent application of established principle; 330 it restrained the savaging of the public fisc by titans of industry who extorted payments of public money as a precondition to providing a private service to private citizens. ${ }^{331}$ The decision proved to be popular among Michigan voters, and every member of the court rendering it was considered as a candidate for higher public office. ${ }^{332}$

There is no reason to doubt that Cooley knew precisely how shocking the decision would be. There is similarly little reason to doubt that he intended it as a rallying cry against what he regarded as widespread knavery. Leggett's old newspaper, the New York World, crowed:

"[T] is a pleasing reflection that, mocked and disregarded as it has been as effete, illiberal, and unprogressive, [the old doctrine's] sound sense and old fashioned honesty are bringing it once more into prominence, approved and vindicated ... . If now reaffirmed in other courts ... and maintained in the press and in the ballot-box, many spoilations may be averted." 333

But too few rallied to the cry for the opinion to have had its intended consequence. While the railroads never succeeded in effecting any change in the Michigan law that would reverse the holding of the Cooley court, they did succeed in preventing the spread of the doctrine so damaging to their interests. ${ }^{334} \mathrm{Had}$ its doctrine been federal law in the 1980s, the Supreme Court might have forbidden the use of federal tax revenues to bail out failed banking institutions and their depositors. And state supreme courts might have forbidden cities and states to compete in giving public funds to private investors in the expectation of creating new jobs stimulating to their local economies, or of attracting professional sports franchises away from other cities.

It is worth noting that the Salem case was singular. When Justice Brandeis cited the Cooley treatise in his famous Ashwander v. Tennessee Valley Authority opinion acclaiming the virtue of judicial self-restraint, ${ }^{335}$ he might also have cited Cooley's dictum in State v. Iron Cliffs Co. ${ }^{336}$ The Iron Cliffs Company challenged the powers of the Tax Commission established by the legislature in 1882. Cooley responded for the court:

If the demurrer is sustained the law will be defeated, and we shall have decided that the Legislature has assumed to exercise authority which does not belong to it. In cases heretofore presented for our examination we have indicated certain rules of propriety and caution which should be observed by us when thus invited to declare void the action of a co-ordinate department of the government,

(holding the Iowa Act of 1868 unconstitutional because the legislature had no power to tax the people to raise funds for a railroad company).

330. The principle that the state cannot give its money away was well-accepted; what was unusual in Cooley's decision was its application to railroad assistance.

331. See, e.g., 9 AM. L. REG. 504 (1870) (commentary by Isaac F. Redfield).

332. See JoNEs, supra note 2 , at 183 .

333. Id. at 180 (quoting Leggett).

334. See, e.g., Township of Pine Grove v. Talcott, 86 U.S. 666, 679 (1873) (holding that state subsidization of railroad construction is not a violation of the Fourteenth Amendment).

335. See Ashwander v. Tennessee Valley Auth., 297 U.S. 288, 345 (1936) (Brandeis, J., concurring).

336. 54 Mich. 350 (1884). 
and to those rules we should be inexcusable if we did not strictly adhere. One of these is, that we must enter upon an examination of a constitutional question like this, assuming that the Legislature has been guilty of no usurpation. We are to remember also that we have no supervisory power in respect to legislation; that the law-making power is not responsible to the judiciary for the wisdom of its acts, and that however unwise or impolitic their acts may appear, they must stand as law unless the Legislature has plainly overstepped its constitutional authority, or lost jurisdiction in the attempt to exercise it, by failing to observe some express constitutional direction. And the case must be clear: a mere doubt on our part of the validity of what the lawmaking department of the government has undertaken to enact, is no ground for annulling it. These are commonplaces in constitutional law: they have often been declared by us, and still more often by other courts. ... [ ] $\mathrm{t}$ is to be feared that courts sometimes, without perhaps being conscious of the fact, proceed in the examination of questions concerning the constitutionality of legislation as if they were at liberty to consider the questions as questions of policy merely .... But every such case is mischievous in its tendency, for it shows that courts lay down proper rules for the government of their own conduct, and then fail to observe them. It is not less important that a court shall keep carefully within its proper jurisdiction than that the Legislature should observe the limits set by the Constitution to its powers ....337

Whether Cooley was always faithful to his own dictum in the cases described above is a question the reader may well raise. Perhaps the cases suggest that Cooley was imperfect in his own self-restraint. To the extent that Cooley imparted his own personal values to constitutional texts, he exhibited the failing against which he protested in Iron Cliffs. On the other hand, insofar as his Jacksonian premises may well have been the "common thoughts of men" in Michigan in his time, Cooley was not unrestrained in his method of interpretation.

The reader may wonder how a judge so solicitous of "the common thoughts of men" failed to gain re-election in 1885. His defeat seems to have had little to do with public reaction to his professional work. Some of his court's decisions on employer liability for work-related injuries drew criticism leveled by the labor movement. ${ }^{338}$ They provide a topic for another day. His criticism of Republican Presidents Grant ${ }^{339}$ and Hayes in nonjudicial writings was likely more significant; ${ }^{340}$ but this is more an explanation for his failure to be ap-

337. Id. at 360-61.

338. See George Edwards, Why Justice Cooley Left the Bench: A Missing Page of Legal History, 10 WAYNE L. REV. 490 (1964).

339. Of Grant, Cooley wrote:

During the whole of his administration, the power of those who control the eighty thousand or so of federal office-holders has been steadily increasing with his assistance, and though in the press and in conventions the will of the people has unmistakably been manifested that this power should be reduced by cutting off the compting patronage, the demand to that effect has never been recognized in the executive mansion.

The Administration of President Grant, 4 INT'L REv. 145, 170 (1877). These words were penned while President Grant was being earnestly importuned to put Cooley on the Supreme Court of the United States.

340. See Thomas M. Cooley \& Abraham S. Hewitt, The Method of Electing the President, 5 INT'L Rev. 198 (1878). 
pointed to the Supreme Court of the United States than for the weakness of Republican support for his re-election. Moreover, it was known that he supported Grover Cleveland, a Democrat, for President in 1884 against the candidacy of William Blaine, a Republican senator widely known for his elastic public morals. ${ }^{341}$ Indeed, Cleveland's campaign slogan, "A public office is a public trust," was known to be Cooley's expression. ${ }^{342}$ Cooley lacked the support of Detroit newspapers for more personal reasons. The owner of one of the papers was an aggressive member of the Board of Regents who had attacked the president of the university, an individual Cooley had publicly and effectively defended. ${ }^{343}$ The other major paper was one against whom Cooley's court had recently rendered an unfavorable decision in a libel case. ${ }^{344}$ His acceptance of the Prohibition Party's nomination might also have been a factor. Temperance, it may be recalled, was another Barnburner tradition, but did not attract the support of many Michiganians. In any case, all these causes of his political weakness may have been inconsequential, given that the voters recorded a "Democratic Deluge" 345 that year in which all Michigan Republican candidates lost.

There is no cause to conclude from this review of Cooley's work that Jacksonian judges held a fundamentally more proper view of the judicial role in constitutional litigation than do judges more attuned to the elitist tradition heralded by Holmes. No case is made here for the election of judges. This brief review does suggest, however, that the judicial role in the constitutional scheme can be responsibly performed by judges who are accountable to the people and who take seriously their duty to keep faith with prevailing moral sentiments and values.

\section{Conclusion and Prospect}

There are no visible portents of a renaissance of the popular democratic tradition in the American legal profession. If anything, the trend lines suggest that the profession is becoming more exclusive, and that judges are becoming increasingly isolated on the hilltop of class pretense. Those trend lines in the profession are, however, a reflection of what is happening in late twentieth

341. "Blaine, Blaine, James G. Blaine, continental liar from the state of Maine!" was a popular cry. For a general history of the 1884 presidential campaign, see Mark D. Hirsch, Election of 1884, in 2 History of ANerican Presidential Elections 1789-1968, at 1561 (Arthur M. Schlesinger ed., 1971). For a contemporaneous account of the Blaine-Cleveland campaign, see FREDERICK E. GOODRICH, THE Life and Public Service of Grover Cleveland 386-97 (Boston, B.B. Russell 1888).

342. See Cooley, supra note 224, at 531.

343. See Lewis G. Vander Velde, Thomas McIntyre Cooley, in Michigan and The Cleveland Era: Sketches of Untversity of Michigan Staff Members who Served the Cleveland AdminisTRATIONS 76, 92 (Earl D. Babst \& Lewis Vander Velde eds., 1948).

344. The case was McLean v. Scripps, 52 Mich. 214 (1883). The paper's attack on Cooley is described in Edwards, supra note 338. The paper described him as an "ingenious sophist" who "covered up with the ermine of the highest tribunal in the commonwealth the shameful record of fraud and corruption" that it had sought to reveal. Id. at 1568 (quoting EventNG NEws, Mar. 16, 1885, at 2). When he lost the election, the Evening News crowed that he had been "unmercifully slaughtered" by 20,000 votes, "[j] ust the number of dollars that were given in a celebrated judgment." Id. at 1572 (quoting Evening News, Apr. 6, 1885, at 1).

345. Vander Velde, supra note 343 , at 92. 
century America as new technologies and the imperatives of free trade impose an ever-deepening cleavage of class lines, dividing the aristocracy of human capitalists who can sell services valued in the world market from their countrymen who cannot.

The Progressive movements of a century ago saved industrial society, capitalism, the market economy, and the institutions of the republic from the inferno depicted by Marx: They prevented the fracturing that is now again appearing on the horizon. A century ago, a technocratic and elite legal profession was a constructive response to the social and political problems of the day. It was recognized as serving a common good; its emergence was part of that good. That may appear to be no longer true. An increasingly elite profession of the law has little to contribute to the stability of a post-industrial society, and may instead be viewed as a growing liability serving to invigorate feelings of hostility and alienation on the part of citizens who increasingly see themselves as nonparticipating objects of a government indifferent to their hopes and interests.

True, it is hard to imagine how we might reverse the process that has brought us to the divisions of class that seem to be magnifying steadily. But it would have been equally difficult in Cooley's time to foresee the evolution, one can almost say revolution, that was beginning to be visible in 1886 and that became an irresistible tide in the first decade and a half of this century.

Perhaps it might lend impetus to a new progressivism if thoughtful men and women begin imagining ways to foster a transition to a profession that more nearly resembles Cooley's than that of Langdell, Holmes, and their adherents and admirers. Such a profession would be less pretentious and more responsive to the interests, the values, and the good of citizens forming the core of the new post-industrial social order, whose "common thoughts" have been given diminishing weight in an era of technocratic elitism. 